\title{
GLOBAL FINANCIAL CRISIS AND SOUTHEAST ASIAN TRADE PERFORMANCE: EMPIRICAL EVIDENCE
}

\author{
Shahriar Kabir ${ }^{1}$ \\ Harry Bloch ${ }^{2}$ \\ Ruhul A Salim*2 \\ ${ }^{1}$ School of Business, Monash University, Malaysia \\ ${ }^{2}$ School of Economics and Finance, Curtin Business School, Curtin University, Australia
}

" Corresponding address: School of Economics \& Finance, Curtin Business School, Curtin University, Perth, WA 6845. Phone: +61 89266 4577, Fax: +61 89266 3026, E-mail: Ruhul.Salim@ @bs.curtin.edu.au 


\title{
GLOBAL FINANCIAL CRISIS AND SOUTHEAST ASIAN TRADE PERFORMANCE: EMPIRICAL EVIDENCE
}

\begin{abstract}
The literature on the recent Global Financial Crisis (GFC) focuses on the decimation of Western economies. However, the impact of the crisis on Asian economies has remained largely unexplored. Using the classic dependency approach of the 'core-periphery' framework, this paper investigates the trade performance of ASEAN members during the GFC (2008-2009) and after the GFC period (2010-2012) and analyses the transmission of shocks to these countries from the Western core. A modified gravity model of trade flows is estimated for a panel of five leading ASEAN economies and their trading partners for the period of 2002 to 2012. The empirical results show a decline in ASEAN trade during the financial crisis, which becomes stronger during the post-crisis period. The decline trade exceeds that associated with changing GDP at home and abroad, suggesting the crisis and its aftermath have been particularly disadvantageous for ASEAN trade.
\end{abstract}

Key Words: global financial crisis; trade; gravity model; ASEAN

JEL Classifications: C23, F10, F14, N75 


\section{GLOBAL FINANCIAL CRISIS AND SOUTHEAST ASIAN TRADE PERFORMANCE: EMPIRICAL EVIDENCE}

\section{Introduction}

The global economy has recently experienced the deepest recession in the post-World War II era, known as the Global Financial Crisis (GFC), which originated in the Western 'core' economy, including the United States of America (US). Most core as well as periphery countries are now in the recovery stage, with a few periphery countries still in the severe recession stage. It is an appropriate time for economists and policy makers to analyze the impact of 'core' generated shocks transmitted to the periphery trading partners and to provide suggestions for future policy directions.

The crisis initially hit the key advanced (core) economies, disrupted the performance of global financial markets and gradually transmitted shocks to periphery countries through the reduction of foreign direct investment (FDI) and trade flows. ${ }^{1}$ This may be seen as a Keynesian demand shock experienced by the Asian periphery countries, that is, a sudden decline in demand from the Western core economies, including the US and other developed countries, for periphery countries' exports. In a recent study, Chor and Manova (2012) suggest that the sharp decline in world trade began in the last quarter of 2008 and accelerated during 2009, eventually exceeding the drop-in world GDP. McKibbin and Stoeckel (2009) attribute the acceleration partly to reappraisal of risk by households and private sector, and partly to increased protectionism by business sector. Reappraisal of risk occurs due to concern about potential contraction of global economy (essentially fueled by global media), which in turn reduces the propensity to consume for the household sector and causes declining investment by businesses.

Though the literature on the recent GFC explores the decimation of the core developed economies, the significance of the crisis in periphery economies, especially for the ASEAN countries, remains largely unexplored. ${ }^{2}$ In a recent study, Hong and Tang (2012) indicate Asian

\footnotetext{
${ }^{1}$ For details, please see Pula (2014), who explains various mechanisms for how the shocks transmitted from the Western core economies, such as the Eurozone, to the periphery, such as West European Balkan economies (Albania, Bosnia and Herzegovina, Bulgaria, Croatia, Kosovo, the Republic of Macedonia, Montenegro, Romania, Serbia, Slovenia).

${ }^{2}$ ASEAN is the Association of South East Asian Nations, which includes Indonesia, Malaysia, Philippines,

Singapore, Thailand, Vietnam, Laos, Cambodia, Brunei and Myanmar.
} 
economies performed better in maintaining economic growth during GFC in spite of less active stimulus effort by their governments compared to OECD economies. However, little is known about how severely Asian exports and imports have been affected in the crisis and post-crisis periods. In particular, ASEAN economies are highly trade dependent, with manufacturing sectors that are export oriented and extensively exposed to the demand of the developed economies.

In the past two decades of globalization, the importance of the major ASEAN economies in global trade has increased. This remarkable advance in ASEAN intra- and extra-regional economic and trade integration occurred after the 1997-98 Asian crisis. ASEAN has developed an intense trade relation with the US, EU (European Union), Australia and major Asian economies, such as China, Japan, Korea and India. Hence, both North-South and South-South trade are important for ASEAN economies. ${ }^{3}$ An in-depth investigation and understanding of the influence of global financial crisis on ASEAN trade is important for anticipating the impact of future crises originated either from either the core economy or the periphery economy (for example, India and China). This study enriches the literature by estimating the effect of the GFC on the exports and imports of the major ASEAN economies with intra- and extra-ASEAN trading partners.

Conventional understanding is that peripheral economies are less vulnerable to crisis than advanced industrialized countries due to their low degree of integration with the centers of financial accumulation. However, ASEAN economies are highly integrated to each other and to the core economy through trade. ASEAN integration to core economies occurs through two channels: The first channel is direct North-South trade link. The second channel is indirect South-South trade link that works through trade of major East Asian economies (for example, China, Japan and South Korea) with the Western economies. ASEAN economies are also interlinked with major East Asian economies through the regional production network. ASEAN firms are involved at different stages of production of a large number of manufacturing products that enter into the Western economies from East Asia (Athukorala, 2010). Hence, reduced trade for East Asia could be translated into less foreign demand for ASEAN intermediate goods, in turn causing trade drops for ASEAN countries.

\footnotetext{
${ }^{3}$ Here, North refers to core of the world economy, consisting of the major advanced industrial nations, and South refers to the remaining periphery economy.
} 
The classic core-periphery analysis of Prebisch (1950) emphasizes the superior position of core economies (the North) as manufacturers of finished consumer and producer goods, while the periphery (the South) has an inferior position in the supply raw materials. This inferior position is reflected in a negative long-period trend in the terms of trade for the South as prices of their exports fall relative to the prices of their imports (Bloch and Sapsford, 2000). Subsequent developments of the theory have extended the subordinate role of the South to the provision of labor-intensive manufactures and services (Wallerstein, 1979; Arrighi, et al, 2003). ASEAN 5 members occupy the role of both producers of raw materials and labor-intensive manufactures, so they may be particularly vulnerable to negative influences on their trading positions from the GFC.

To determine the impact of the GFC on ASEAN, we examine annual export and import data from 2002 to 2012 for 5 large ASEAN countries, Indonesia, Malaysia, Philippines, Singapore and Thailand, among themselves and with 11 major trading partners, which covers $75 \%$ of ASEAN trade. ${ }^{4}$ We estimate a modified gravity model for the five chosen ASEAN economies and their trading partners. Gravity models link a country's exports and imports to the distance from a trading partner, which reflects the transactions cost of that trade, and the partner's GDP, which reflects its potential for demanding exports and supplying imports. We modify this basic model by adding dummy variables for the crisis period and for the post-crisis period, which capture any residual impacts on trade that may be due to the subordinate position of the countries in the international trading system.

Considering 2008-2009 as the crisis period and 2010-2012 as the post-crisis period, our estimation results show ASEAN members' exports and imports with their major trading partners rise and fall with GDP in their trading partners as predicted by the basic gravity model. In addition to these changes, ASEAN exports and imports both decline further during the GFC and its aftermath. Thus, during the crisis period both declining GDP in trading partners and the residual effect captured by the crisis dummy negatively affect ASEAN trade, while in the postcrisis period rising trading-partner GDP has a positive effect on trade partially or fully offsetting the prolonged negative effect from the post-crisis dummy variable.

\footnotetext{
${ }^{4}$ We start with 2002 to avoid the aftermath of the Asian financial crisis, as this crisis had dramatic impact and may have altered the structural trading patterns for ASEAN economies.
} 
The remainder of this paper is organized as follows. The next section briefly discusses ASEAN trade flows in recent years, while Section 3 outlines the analytical framework as well as the data and variables. Section 4 presents the econometric results and interpretations. Section 5 presents calculations of the separate impact of the GFC and GDP changes on bilateral trade flows, while Section 6 provides robustness checks. The last section concludes the paper, drawing policy implications for post-GFC regional trade policies in ASEAN.

\section{ASEAN Post-Crisis Trade Decline: Overview}

ASEAN is among the regional trading blocs making significant progress in developing intra- and extra-regional economic relationships, though diverse opinion exists in the literature about the extent of the integration process (for example, Sally and Sen, 2005; Rana, 2007; Pomfret and Sourdin, 2009). ${ }^{5}$ The ASEAN Free Trade Area (AFTA) was introduced with the objective to develop regional competitive advantages, including improving the economic efficiency and productivity of its member nations. AFTA removes tariff and non-tariff barriers within the region. ASEAN members has also developed free-trade agreements outside the region. These include the ASEAN - Republic of Korea Free Trade Area, ASEAN - Japan Free Trade Area, ASEAN - India Free Trade Area, ASEAN - China Free Trade Area and ASEAN - Australia New Zealand Free Trade Area. In addition, the region has relations with Canada, the European Union, Russia, the US and Pakistan. ${ }^{6}$

At the beginning of $21^{\text {st }}$ Century, ASEAN members had just recovered from the severe 1997-1998 Asian economic crisis. The crisis led ASEAN policy makers towards stronger regional economic integration rather than towards individual protectionism. Without solid economic integration in the whole ASEAN region, the individual economy is more vulnerable to shocks from the Western core economies, such as due to GFC. The success of this effort is remarkably reflected in ASEAN trade performance. The region has become an important factor in world trade (Richardson, 2005). Figure 1 shows recent success in the exports and imports of five major ASEAN economies.

\footnotetext{
${ }^{5}$ Most criticism of ASEAN integration focusses on the complexity of too many regional and bilateral trade agreements. Sally and Sen (2005) express the concern that the excessive number of trade agreements leads to trade diversion from members.

${ }^{6}$ Information collected from ASEAN's official website - www.asean.org
} 
Figure 1 illustrates exports and imports of the ASEAN 5 from 1994 to $2013 .{ }^{7}$ Both exports and imports show reasonable progress until 1996, followed by a remarkable decline (of imports in particular) during the Asian Crisis. The recovery period continues until 2002-2003, followed by a notable improvement in trade. The success story, however, is disrupted badly during 2008-2009 GFC. In the immediate post-GFC period, the amount of trade growth (in terms of exports and imports) is large by pre-GFC standards. However, growth slows down again in 2011 for some countries. In 2012 and 2013, the slow growth trend continues, while exports and imports even drop for some countries.

Figure 1: ASEAN 5 trade flows (in billion USD)

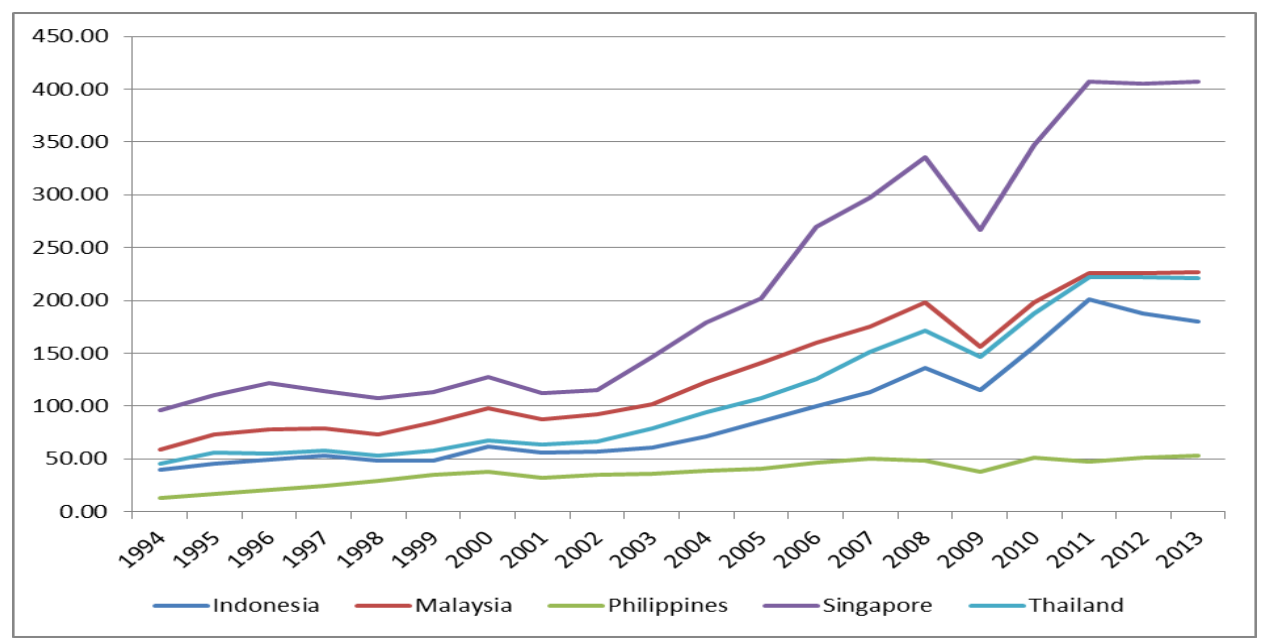

(a) Exports

\footnotetext{
${ }^{7}$ ASEAN 5 includes Indonesia, Malaysia, Philippines, Singapore and Thailand.
} 


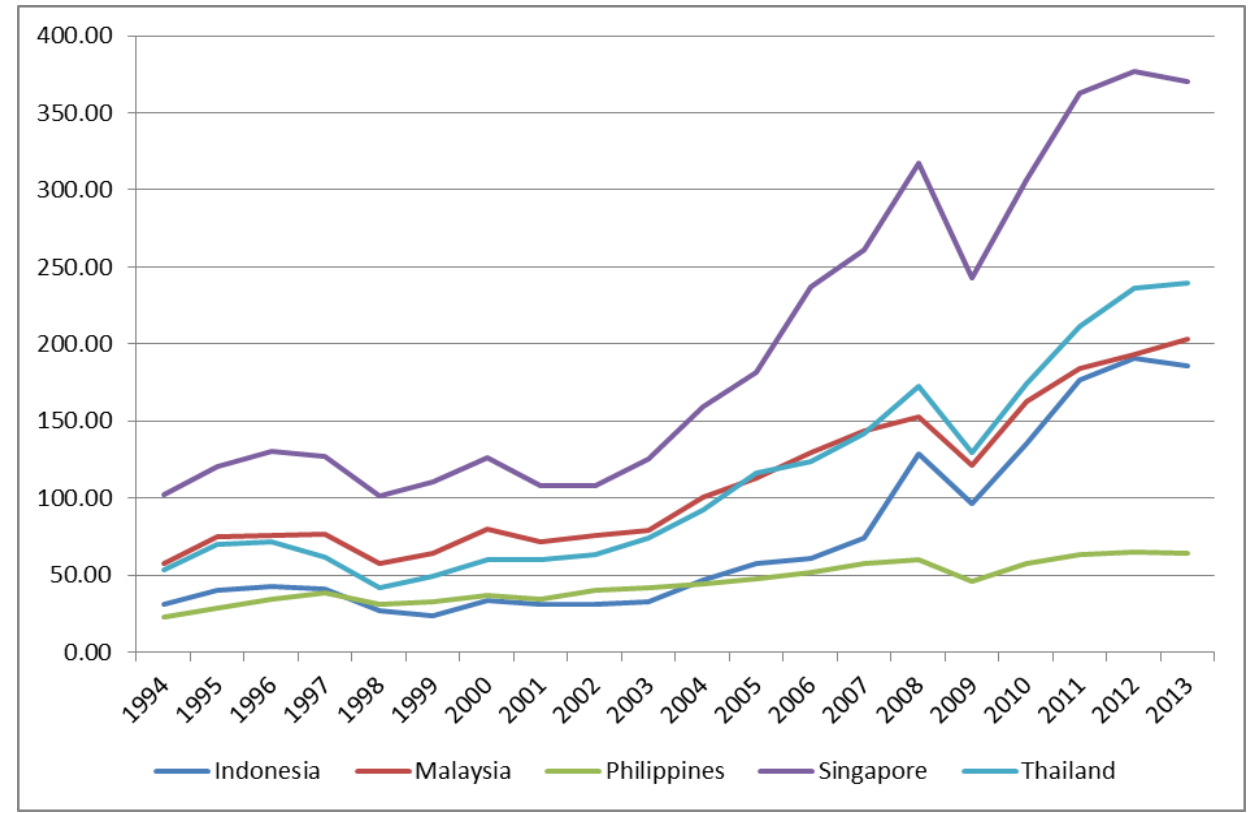

(b) Imports

[Source: Authors' calculation based on data from World Bank WDI database]

Figure 2 presents the year-on-year change in the exports and imports of the ASEAN 5. A few remarks are worthwhile about this figure. Since 1995, the major decline in ASEAN trade occurs during the GFC (surprisingly, the trade drop during the GFC is much higher than during the Asian crisis). Both exports and imports start to decline from mid-2008, drop deeper during 2009 and revive by early 2010. According to conventional wisdom, this recovery should continue over a couple of years, but ASEAN trade flows reflect a different pattern.

\section{Figure 2: Year-on change in ASEAN trade flows (in billion USD)}

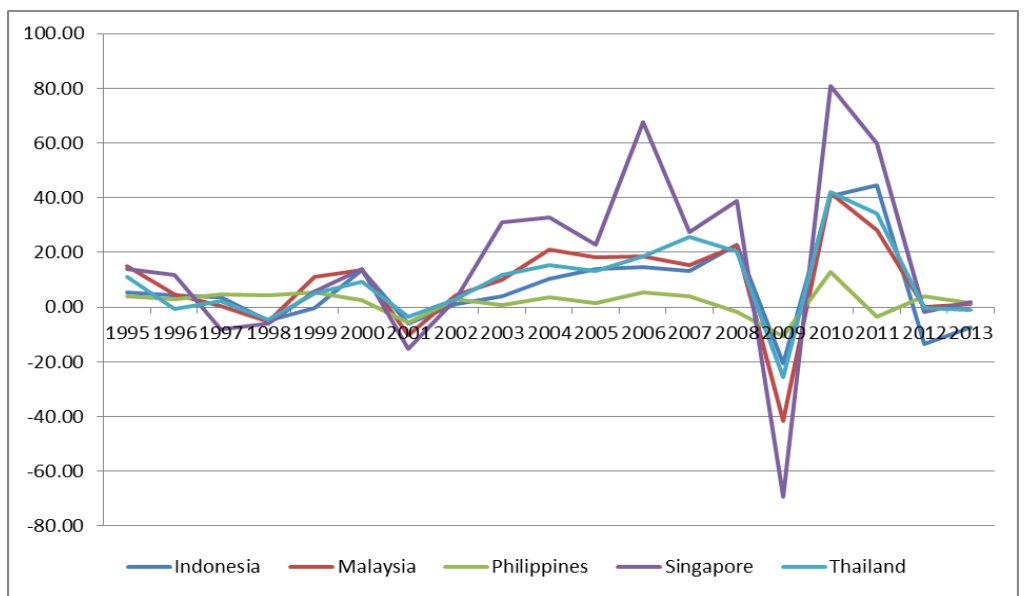

(a) Exports 


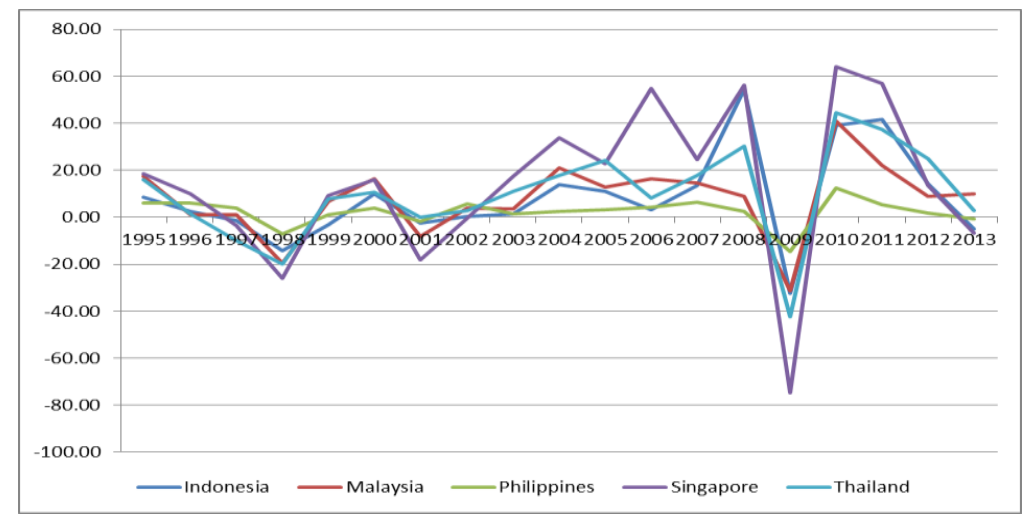

(b) Imports

[Source: Authors' calculation using data from Figure 1]

The growth rate of ASEAN trade flow shows a declining tendency during mid-2010 to 2011, deepening in 2012. During this period, the exports of the Philippines and Indonesia fall in the negative zone of year-on-change, whereas for other countries, the export growth rate drops but remains positive. However, for all countries, an increase in the export growth rate takes place in 2013. Similar to that for exports, the story of the declining growth rate also stands for ASEAN imports during 2012-2013, and Singaporean import growth is negative for 2013. Thus, both Figure 1 and Figure 2 suggest that the post-GFC effect of slowing trade growth extends till 2012, but that the decline is smaller than in the GFC period.

\section{Analytical Framework and Data}

Economists and commentators often blame the poorly regulated banking system in the US for creating excessive global savings and generating the GFC (for example, Krugman, 2009). In particular, enormous financial imbalances accumulated during the late $20^{\text {th }}$ Century and early $21^{\text {st }}$ Century around the world. (Merrouche and Nier, 2010). The effects of the GFC spread in varying degrees to all parts of the world.

There are two schools of thought with regard to how shocks are transmitted to periphery economies from the Western core economies. Keynesian views identify changes in exports due to changes in income impacting consumption demand, which are incorporated in the gravity model of export (import) flows through positive coefficients of a trading partner's (domestic) GDP. In addition to a demand for goods from abroad, trade requires a supply from the domestic economy, which is captured through a positive coefficient of domestic (trading partner) GDP in the equation for export (import) flows. The Keynesian effect should create a negative force on 
trade as GDP falls at home and abroad during crisis period. During post-crisis period, economic recovery through increased foreign (domestic) GDP then creates a positive demand for exports (imports) to (from) each trading partner, while increased domestic (foreign) GDP provides the supply to meet this demand.

The other view comes from the core-periphery approach, with core economies controlling trade relations with peripheral countries to the advantage of the core. Under this view, the GFC may have additional adverse trade consequences for the periphery both during and after the crisis as the core adjusts trading relationships to protect home interests through protectionism and reorienting supply chains. ${ }^{8}$ This view is incorporated in the model by separating the post-crisis period (2010-12) from the crisis period (2008-09). These two views, along with the neoclassical gravity modeling (explained under empirical model), comprise the analytical framework of this study. Overall, ASEAN trade should be negatively affected by both Keynesian effects and coreperiphery effects during the crisis period. During post-crisis period, the core-periphery effects should be partially or fully offset by the positive Keynesian effects.

The analysis proceeds at two stages. First, the augmented gravity model is estimated to directly capture the core-periphery effect of crisis and post-crisis period, results are presented in Section 4. Second, specific values are plugged-in to the estimated model to calculate the Keynesian effect during crisis and post-crisis period, with results of the calculation presented in Section 5 .

\subsection{Empirical model}

Tinbergen (1962) and Pöyhönen (1963) propose that trade between two partners is proportional to the product of their GDP and inversely proportional to their geographical proximity. Anderson (1979) and Bergstrand $(1985,1989)$ extend the model to provide a 'theoretical foundation'. In later studies, Anderson and Wincoop (2003) establish the use of GDP as a proxy for the exporter's production capacity and the importer's market size. In another study, Anderson and Wincoop (2004) emphasize the importance of trade cost, which is commonly captured in the gravity model by using distance as a proxy. Subsequently, additional explanatory variables have been added to analyze different perspectives on trade relations (Engel and Rogers, 1996; Frankel

\footnotetext{
${ }^{8}$ Fischer (2015) gives a detailed exposition with symbiosis changes of other factors that show the contemporary global development (see also Pula, 2014). A related view focusses on the adverse consequences of changes in the terms of trade for periphery countries as suppliers of raw materials and intermediate products arising from the market power of the core industrialized countries (Bloch and Sapsford, 2000).
} 
and Romer, 1999; Eaton and Kortum, 2002; Kimura and Lee, 2006; Kabir and Salim, 2010). In some recent studies, the gravity model is used to analyze the effects of exchange rate volatility, trade liberalization and regional integration on east Asian trade flows (Chit, Rizov and Willenbockel, 2010; Jongwanich, 2010; Sheng, Tang and Xu, 2014). However, to our knowledge, this is the first study to analyze the effects of the GFC on ASEAN trade flows through applying the gravity model.

The gravity model used in this study is as follows:

$\ln$ trade $_{x y t}=\beta_{0}+\beta_{1} \ln g d p_{x t}+\beta_{2} \ln g d p_{y t}+\beta_{3} \ln d i s t_{x y}+\beta_{4} C L B_{x y}+\varepsilon_{x y t}$

Here, trade $x_{x y t}$ is the exports (imports) of the ASEAN 5 member (country x) going to (coming from) a trading partner (country y), $g d p_{x}$ is the GDP of country $\mathrm{x}, g d p_{y}$ is the GDP of country $\mathrm{y}$, dist $_{x y}$ is the distance between the trade partners $\mathrm{x}$ and $\mathrm{y}$, and $\varepsilon_{x y t}$ is the error term. $\mathrm{C} L B_{x y}$ is the common land border dummy, which is 1 if the country-pair share common land border and " 0 " otherwise. The expected signs for the coefficients of these standard gravity variables are $\beta_{1}>0, \beta_{2}>0, \beta_{3}<0, \beta_{4}>0$.

Our objective is to estimate the effects of the GFC on ASEAN trade. The GFC originated in Western economies, particularly in the US and transmission of the crisis to Asia would not occur immediately (see Figure 2). Two dummies are added to the model in Equation (1) to account for the impact of the GFC on trade: one for the period of GFC in 2008-2009 and the other for the post-crisis period in 2010-2012. ${ }^{9}$ The dummy variables pick up impacts above and beyond any change due to changes in GDP at home and abroad. The model is:

$\ln$ trade $_{x y t}=\beta_{0}+\beta_{1} \ln g d p_{x t}+\beta_{2} \ln g d p_{y t}+\beta_{3} \ln$ dist $_{x y}+\beta_{4} C L B_{x y}+\beta_{5}$ crisis $_{t}+\beta_{6}$ postcrisis $_{t}+\varepsilon_{x y t}$

Here, crisist equals "1" for the years 2008 and 2009 and "0" otherwise. Similarly, postcrisis equals " 1 " for the years 2010, 2011 and 2012 and "0" otherwise.

According to the standard gravity model, $\beta_{5}$, the crisis dummy coefficient, and $\beta_{6}$, the post-crisis dummy variable, are zero as only normal supply and demand captured through GDP variables affect trade. However, the core-periphery approach suggests there are adverse effects of

\footnotetext{
${ }^{9}$ Our main focus is on impacts on aggregate trade, but the variation of effects across industries is considered as a robustness check with results presented in Section 6, along with results from a model that seeks to identify the proximate causes of the crisis and post-crisis effects.
} 
the crisis and aftermath on the trade of the periphery due to manipulation of trade relations by the core. Hence, the signs of $\beta_{5}$ and $\beta_{6}$ are crucial in this study, with a negative sign indicating a structural change to the disadvantage of the trade of ASEAN members.

In this study, export and import equations are estimated separately as follows:

$\ln \exp _{x y t}=\beta_{0}+\beta_{1} \ln g d p_{x t}+\beta_{2} \ln g d p_{y t}+\beta_{3} \ln d i s t_{x y}+\beta_{4} C L B_{x y}+\beta_{5}$ crisis $_{t}+\beta_{6}$ postcrisis $_{t}+\varepsilon_{x y t}$

$\ln i m p_{x y t}=\gamma_{0}+\gamma_{1} \ln g d p_{x t}+\gamma_{2} \ln g d p_{y t}+\gamma_{3} \ln d i s t_{x y}+\gamma_{4} C L B_{x y}+\gamma_{5}$ crisis $_{t}+\gamma_{6}$ postcrisis $_{t}+\varepsilon_{x y t}$

For exports, country $\mathrm{x}$ is the exporting country (also mentioned as the reporting country) and country $\mathrm{y}$ is the trading partner. For imports, country $\mathrm{y}$ is the reporting country and country $\mathrm{x}$ is the trading partner. Technically, both exports and imports are the same relation apart from the two opposite directions of trade flows. However, not all trading partners are included in the sample of reporting countries so total exports for the data sample don't equal total imports unless trade is balanced. As shown in Figure 1, there are distinct impacts of the GFC separately on ASEAN exports and imports.

Some literature (for example, Chit, Rizov and Willenbockel, 2010) suggests estimation of the gravity model using fixed effects may not be reliable because of potential endogeneity. A growing trend has been to estimate the dynamic panel using the instrumental variable (IV) technique or the generalized method of moments (GMM) technique to address endogeneity. However, the estimation accuracy of these techniques greatly varies with the choice of instruments and related aspects (Stock, Wright and Yogo, 2002; Kiviet and Feng, 2014; Kiviet, Pleus and Poldermans, 2015). For example, the speed of dynamic adjustment, the presence of endogenous regressors, the types and severity of heteroscedasticity in GMM are beyond control of the investigator (Kiviet, Pleus and Poldermans, 2015). Instead, Sheng, Tang and Xu (2014) suggest that the endogeneity issue can be avoided by using country-specific effects. Thus, the dominant gravity literature relies on the static panel estimation approach (for example, Sheng, Tang and Xu, 2014; Athukorala, 2010; Egger, 2002). In particular, our study follows Egger (2002), who suggests choosing between fixed effect and random effect estimations using the Hausman-Taylor method (Hausman and Taylor, 1981). In addition, Egger (2002) suggests using the estimation method proposed by Hausman and Taylor (HT) in the presence of cross-sectional correlation of residuals and this method adjusted for first-order autoregressive disturbances (HT $\mathrm{AR}(1))$ in presence of autocorrelation of the residuals. 


\subsection{Description and sources of data}

We estimate determinants of the trade of 5 ASEAN members among themselves and with their major non-member trading partners. ${ }^{10}$ The non-member countries are those at the top of the list of ASEAN trade partners in terms of trade volume. Further, ASEAN has developed a free trade area with Australia and New Zealand, so Australia and New Zealand are included in the list of trading partners. The EU members are excluded from this study to avoid influence of the Euro crisis, but then included later to provide a robustness check. ${ }^{11}$ Vietnam is included as a trade partner for other ASEAN members, but not as a panel country due to missing data. Thus, sixteen trading partner countries are selected (see list in Appendix Table 1): six are ASEAN members and ten are non-members that cover about $75 \%$ of ASEAN trade (see Appendix Table 2).

The estimating equations for imports and exports include the dummy variables for the GFC period (2008 and 2009) and for the post-GFC period (2010-2012) along with standard gravity equation variables, GDP for the home country and trading partner, distance between trading partners and whether the countries share a common land border. Annual data on exports and imports are collected from the World Integrated Trade Solution UNCOMTrade database. GDP data are collected from the World Bank World Development Indicator (WDI) database. Distance between countries is calculated based on the country location provided by the CIA World Factbook. Information on common land borders is also collected from the CIA World Factbook database.

\section{Discussion of Results: Analysis of Trade Flows}

Export (Equation 3) and import (Equation 4) models are estimated separately, yielding 2 sets of results from the panel data. Both fixed effect (FE) models and random effect (RE) models are estimated for each panel. Hausman's specification test (Hausman, 1978) is used to examine the existence of a correlation between the error terms and the regressors. If a correlation exists, the fixed effect approach is preferred. Otherwise, the random effect approach is preferred. Both

\footnotetext{
${ }^{10}$ Indonesia, Malaysia, Philippines, Singapore and Thailand are commonly known as the ASEAN 5. The other 5 ASEAN countries are excluded from this study due to missing data.

${ }^{11}$ Though the EU crisis originated from the GFC, the consequences of EU crisis and the GFC are different. The current study is designed to investigate in depth of the consequences of GFC in ASEAN trade, hence combining two consequences is out of scope to this study. However, as a robustness check, we estimate a panel including as trading partners the 6 major EU countries (France, Germany, Italy, Netherlands, Spain and United Kingdom) EU members in terms of their economic size and trade values.
} 
models are estimated using the robust option. ${ }^{12}$ This approach produces standard errors that are 'robust to arbitrary patterns of heteroscedasticity in the data' (Shepherd, 2013, p.28). ${ }^{13}$ If serial correlation is detected, first-order autoregressive adjustment is used to obtain corrected estimates. As variables are measured in natural logarithms, the estimated coefficients represent elasticity, i.e., the coefficients can be interpreted as the percentage change in trade due to a oneunit change in each explanatory variable.

Estimation proceeds in three stages for both exports and imports. Initially, the standard gravity model is estimated, then the crisis and the post-crisis dummies are added to capture the impact of GFC on ASEAN trade. Finally, the models are estimated separately for intra-ASEAN and extra-ASEAN trade. The estimation results are presented in Table 1 and Table 2 for the export model and in Table 3 and Table 4 for the import model.

\section{1 Export analysis}

For the export model, the first three columns of Table 1 show the estimation of the standard gravity model for exports, while columns 4 to 6 show the estimation of the augmented gravity model. The results for intra- and extra-ASEAN exports are shown in Table 2, where estimation results for intra-ASEAN exports are presented in Columns 1 to 4 and those for extra-ASEAN exports in Columns 5 to 7.

The Hausman test does not reject the null hypothesis that the coefficients of the FE model and the coefficients of the RE model are equal, except for the intra-ASEAN model. Hence, apart from intra-ASEAN exports, the estimates of the RE models are preferred to the FE models. The Breusch-Pagan Lagrange Multiplier (LM) also supports a random effects regression over a simple OLS regression. However, the serial correlation test rejects the null hypothesis that there is no serial correlation for some models. Hence, we re-estimate the standard gravity model, the augmented gravity model and the extra-ASEAN exports model using the Hausman-Taylor method with adjustment for first-order autocorrelation (HT AR(1)) as recommended by Hausman and Taylor (1981), Egger (2002) and Baltagi et al. (2003). Similarly, we use the HT method without adjustment for first-order autocorrelation for estimating intra-ASEAN exports to

\footnotetext{
12 The Hausman test cannot be used for robust estimation, so the Hausman test statistic for RE vs FE is based on the original standard errors.

13 The RE model is also estimated using a maximum likelihood estimator (MLE), yielding virtually identical estimated coefficients, which can be obtained from the authors on request.
} 
correct for cross-sectional correlation of residuals. Estimates from applying the HT method are efficient and consistent as long as the over-identifying restrictions of the method are satisfied.

Table 1: ASEAN exports

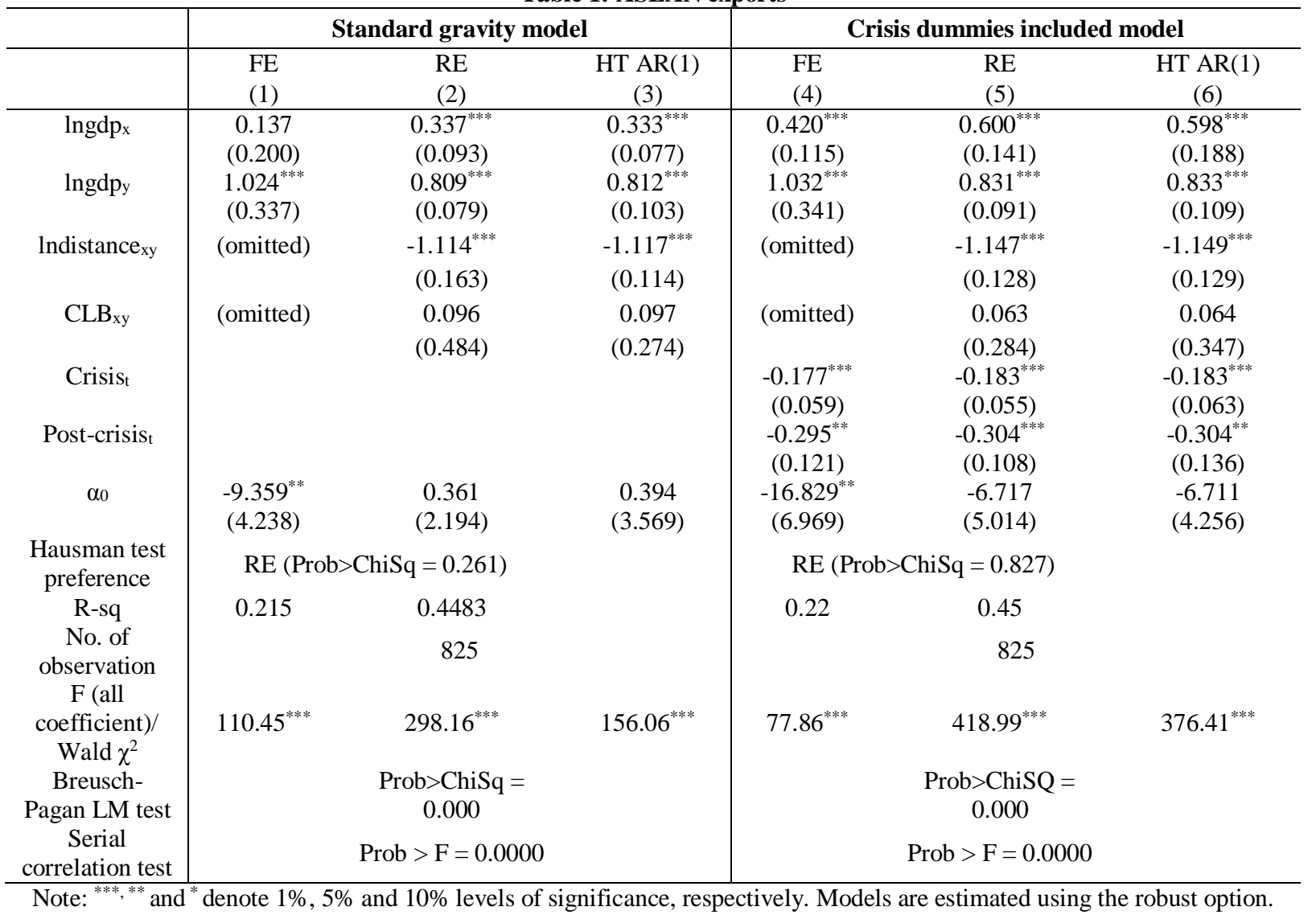

The model's ability to explain ASEAN exports is moderate, except for intra-ASEAN exports, which is low and suggests there is either substantial random disturbance in exports or omitted variables have substantial influence. Particular caution is therefore required in interpreting the intra-ASEAN results. Estimates for the standard gravity model (Columns 1 and 2 of Table 1) are found to be generally statistically significant and with expected signs, though the common land border effect is consistently insignificant. Column 3 presents the HT AR(1) estimates, which do not vary much from the RE estimates. Estimates of the demand effect from GDP of the destination country are uniformly more positive than the corresponding supply effect of GDP in the source country, particularly supporting a Keynesian demand interpretation of the results.

Results from the augmented model with the two crisis dummies are presented in Columns 4, 5 and 6 of Table 1. The coefficient estimates of the standard gravity variables of Column 4 and 
5 are similar to those in Columns 1 and 2, apart from the higher coefficient value for the exporter's GDP. Coefficient estimates for the crisis and post-crisis dummies suggest that exports of ASEAN members are significantly reduced during and after the Global Financial Crisis, which supports the view that trading patterns have been altered to the disadvantage of ASEAN members as expected in the core-periphery analysis. In the results using the HT AR(1) method with its superior econometric properties, ASEAN exports decline by $17 \%\left(1-\mathrm{e}^{-0.183}\right)$ during the GFC period and by $26 \%\left(1-\mathrm{e}^{-0.304}\right)$ during the post-GFC period in addition to the impact of changing GDP at home and abroad. Adjusting for the different number of years involved, the negative impact of the crisis and its aftermath on ASEAN is estimated at about 9\% per year throughout.

Next, the augmented model is estimated separately for exports to ASEAN members (intra-ASEAN exports) and for exports from ASEAN members to non-member trading partners (extra-ASEAN exports), with the results presented in Table 2. The results for intra-ASEAN exports are shown in Columns 1 to 4, and those for extra-ASEAN exports are shown in Columns 5 to 7 . In both cases, the coefficients of standard gravity variables estimated by the FE and the RE models are generally significant, with the expected sign, aside from the insignificant coefficients for the common land border and for the GDP variables in the intra-ASEAN results using the FE estimates.

For the intra-ASEAN export model, the Hausman test rejects the null hypothesis that the coefficients of the FE model and the coefficients of the RE model are equal. Hence, the estimates of the FE model are preferred to those of the RE model. There are two types of fixed effects models: one is country fixed effects model and the other is country and time fixed effects model. Shepherd (2013) suggests a time fixed effect test to identify which fixed effects model is more suitable. For intra-ASEAN trade Shepherd's time fixed effect test rejects the null hypothesis and indicates the time and country fixed effect model is needed as the year coefficients are not jointly equal to zero. Estimated results for the country and time fixed effect (TFE) models are presented in Column 3. However, the cross-sectional dependence test using the Pesaran method rejects the null hypothesis that the residuals across entities are uncorrelated. Hence, we use the Hausman Taylor method (HT) for estimation, as suggested by Egger (2002), with results presented in Column 4. 
Table 2: Intra- and extra-ASEAN exports

\begin{tabular}{|c|c|c|c|c|c|c|c|}
\hline & \multicolumn{4}{|c|}{ Crisis dummies included in the intra-ASEAN model } & \multicolumn{3}{|c|}{ Crisis dummies included in the extra-ASEAN model } \\
\hline & $\begin{array}{l}\mathrm{FE} \\
(1)\end{array}$ & $\begin{array}{l}\mathrm{RE} \\
(2)\end{array}$ & $\begin{array}{l}\text { TFE } \\
\text { (3) }\end{array}$ & $\begin{array}{l}\mathrm{HT} \\
\text { (4) }\end{array}$ & $\begin{array}{l}\mathrm{FE} \\
(5)\end{array}$ & $\begin{array}{l}\mathrm{RE} \\
(6)\end{array}$ & $\begin{array}{c}\text { HT AR(1) } \\
(7)\end{array}$ \\
\hline $\operatorname{lngdp_{x}}$ & $\begin{array}{c}-0.88 \\
(1.299)\end{array}$ & $\begin{array}{l}0.776^{* *} \\
(0.340)\end{array}$ & $\begin{array}{c}0.595 \\
(0.757)\end{array}$ & $\begin{array}{c}0.643 \\
(0.496)\end{array}$ & $\begin{array}{c}0.450^{* * * *} \\
(0.09)\end{array}$ & $\begin{array}{c}0.447^{* * * *} \\
(0.09)\end{array}$ & $\begin{array}{c}0.447^{* * * *} \\
(0.06)\end{array}$ \\
\hline $\operatorname{lngdp} y$ & $\begin{array}{c}2.923 \\
(2.085)\end{array}$ & $\begin{array}{l}0.592^{* * *} \\
(0.285)\end{array}$ & $\begin{array}{c}4.321 \\
(2.666)\end{array}$ & $\begin{array}{c}1.181^{\text {**** }} \\
(0.450)\end{array}$ & $\begin{array}{c}0.767^{* * * *} \\
(0.10)\end{array}$ & $\begin{array}{c}0.775^{\text {**** }} \\
(0.09)\end{array}$ & $\begin{array}{c}0.776^{* * * *} \\
(0.06)\end{array}$ \\
\hline lndistance ${ }_{\mathrm{xy}}$ & (omitted) & $\begin{array}{c}-1.167^{* * * *} \\
(0.195)\end{array}$ & (omitted) & $\begin{array}{l}-1.114^{*} \\
(0.589)\end{array}$ & (omitted) & $\begin{array}{l}-1.001^{* * * *} \\
(0.25)\end{array}$ & $\begin{array}{c}-1.001^{* * *} \\
(0.27)\end{array}$ \\
\hline $\mathrm{CLB}_{\mathrm{xy}}$ & (omitted) & $\begin{array}{c}0.016 \\
(0.254)\end{array}$ & (omitted) & $\begin{array}{l}-0.038 \\
(0.877)\end{array}$ & (omitted) & (omitted) & (omitted) \\
\hline Crisist & $\begin{array}{l}-0.571^{*} \\
(0.333)\end{array}$ & $\begin{array}{l}-0.167 \\
(0.142)\end{array}$ & $\begin{array}{c}-2.425^{* * * *} \\
(1.171)\end{array}$ & $\begin{array}{l}-0.411 \\
(0.310)\end{array}$ & $\begin{array}{c}-0.074^{* * *} \\
(0.03)\end{array}$ & $\begin{array}{c}-0.075^{* * *} \\
(0.03)\end{array}$ & $\begin{array}{c}-0.075^{* *} \\
(0.03)\end{array}$ \\
\hline Post-crisist & $\begin{array}{c}-0.86 \\
(0.589)\end{array}$ & $\begin{array}{c}-0.27 \\
(0.264)\end{array}$ & $\begin{array}{c}-3.903^{* * * *} \\
(2.025)\end{array}$ & $\begin{array}{l}-0.644 \\
(0.391)\end{array}$ & $\begin{array}{c}-0.138^{* * * *} \\
(0.04)\end{array}$ & $\begin{array}{c}-0.14^{* * * *} \\
(0.04)\end{array}$ & $\begin{array}{c}-0.140^{* * * *} \\
(0.04)\end{array}$ \\
\hline$\alpha_{0}$ & $\begin{array}{l}-30.37 \\
(20.926)\end{array}$ & $\begin{array}{c}-4.937 \\
(12.493)\end{array}$ & $\begin{array}{c}-103.718^{* * * *} \\
(57.044)\end{array}$ & $\begin{array}{l}-16.939 \\
(11.729)\end{array}$ & $\begin{array}{c}-11.007^{* * *} \\
(1.89)\end{array}$ & $\begin{array}{l}-2.537 \\
(2.89)\end{array}$ & $\begin{array}{l}-2.542 \\
(2.60)\end{array}$ \\
\hline $\begin{array}{l}\text { Hausman test } \\
\text { preference }\end{array}$ & \multicolumn{2}{|c|}{$\begin{array}{c}\mathrm{FE}(\text { Prob }>\mathrm{ChiSq}= \\
0.0374)\end{array}$} & & & \multicolumn{2}{|c|}{$\mathrm{RE}(\operatorname{Prob}>\mathrm{ChiSq}=0.9654)$} & \\
\hline $\begin{array}{l}\text { R-square } \\
\text { No. of }\end{array}$ & 0.03 & 0.246 & 0.036 & & 0.47 & 0.58 & \\
\hline $\begin{array}{c}\text { observation } \\
\text { F (all }\end{array}$ & & & 275 & & & 550 & \\
\hline $\begin{array}{l}\text { coefficient)/ } \\
\text { Wald } \chi^{2}\end{array}$ & $11.7^{* * * *}$ & $219.03^{* * *}$ & $127.95^{* * *}$ & $43.89^{* * *}$ & $99.62^{* * *}$ & $459.04^{* * *}$ & $476.02^{* * * *}$ \\
\hline $\begin{array}{l}\text { Breusch- } \\
\text { Pagan LM } \\
\text { test }\end{array}$ & & & & & & $\begin{array}{l}\text { Prob }>\text { ChiSq } \\
\quad=0.00\end{array}$ & \\
\hline $\begin{array}{c}\text { Serial } \\
\text { correlation } \\
\text { test }\end{array}$ & & & & & & $\begin{array}{c}\text { Prob }>\mathrm{F}= \\
0.00\end{array}$ & \\
\hline $\begin{array}{l}\text { Time fixed } \\
\text { effects test }\end{array}$ & & & $4.56^{* * *}$ & & & & \\
\hline $\begin{array}{c}\text { Pesaran CD } \\
\text { Test }\end{array}$ & & & $\begin{array}{c}24.785^{* * *} \\
\mathrm{ABS}=0.572\end{array}$ & & & & \\
\hline
\end{tabular}

As noted above, the low $\mathrm{R}$ for the intra-ASEAN results suggests the need for caution in interpreting these results. There is also instability in the estimated coefficients across the different estimation methods as compared to the extra-ASEAN results. Focusing only on the estimates for extra-ASEAN exports from the HT AR(1) method, ASEAN exports decline by $7 \%$ $\left(1-\mathrm{e}^{-0.075}\right)$ during the GFC period and by $13 \%\left(1-\mathrm{e}^{-0.140}\right)$ during the post-GFC period beyond what can be attributed to changes in GDP at home and abroad.

\subsection{Import analysis}

ASEAN imports are also analyzed in three stages. First, the standard gravity model is estimated with the estimation results presented in Columns 1 and 2 of Table 3. The Hausman test rejects 
the null hypothesis that the coefficients of the FE model and the coefficients of the RE model are equal. Hence, the estimates of the FE model is preferred to those of the RE model. Second, the crisis and post-crisis dummies are included in the gravity model. The estimation results for the FE and RE models are presented in Columns 3 and 4 of Table 3. The Hausman test rejects the null hypothesis and prefers the FE model to the RE model. Hence, the country fixed effect model is estimated, followed by a time and country fixed effect model and then a test to identify which fixed effects model is more suitable. This test concludes that the time fixed effect model is needed, so results for the latter model are presented in Column 5. Further, the cross-sectional dependence test using Pesaran method suggests that the residuals across countries in the TFE results are correlated. Hence, we re-estimate the model using the HT method as suggested by Egger (2002) and the results are presented in Column 6.

Table 3: ASEAN imports

\begin{tabular}{|c|c|c|c|c|c|c|}
\hline & \multicolumn{2}{|c|}{ Standard gravity model } & \multicolumn{4}{|c|}{ Crisis dummies included model } \\
\hline & $\begin{array}{l}\mathrm{FE} \\
(1)\end{array}$ & $\begin{array}{l}\mathrm{RE} \\
(2)\end{array}$ & $\begin{array}{l}\mathrm{FE} \\
\text { (3) }\end{array}$ & $\begin{array}{l}\mathrm{RE} \\
(4)\end{array}$ & $\begin{array}{l}\text { TFE } \\
(5)\end{array}$ & $\begin{array}{l}\text { HT } \\
\text { (6) }\end{array}$ \\
\hline $\operatorname{lngdp}_{\mathrm{x}}$ & $\begin{array}{l}0.878^{* * *} \\
(0.358)\end{array}$ & $\begin{array}{l}0.767^{* * * *} \\
(0.068)\end{array}$ & $\begin{array}{l}0.887^{* * *} \\
(0.360)\end{array}$ & $\begin{array}{c}0.775^{* * *} \\
(0.071)\end{array}$ & $\begin{array}{c}0.948^{* * * *} \\
(0.280)\end{array}$ & $\begin{array}{c}0.781^{* * *} \\
(0.07)\end{array}$ \\
\hline $\operatorname{lngdp} p_{y}$ & $\begin{array}{c}0.376 \\
(0.243)\end{array}$ & $\begin{array}{l}0.41^{* * * *} \\
(0.090)\end{array}$ & $\begin{array}{l}0.704^{* * * *} \\
(0.171)\end{array}$ & $\begin{array}{c}0.492^{* * * *} \\
(0.146)\end{array}$ & $\begin{array}{l}1.416^{* * * *} \\
(0.470)\end{array}$ & $\begin{array}{c}0.528^{* * * *} \\
(0.137)\end{array}$ \\
\hline lndistance ${ }_{x y}$ & (omitted) & $\begin{array}{c}-0.813^{* * * *} \\
(0.116)\end{array}$ & (omitted) & $\begin{array}{c}-0.824^{* * * *} \\
(0.115)\end{array}$ & (omitted) & $\begin{array}{c}-0.831^{* * * *} \\
(0.142)\end{array}$ \\
\hline $\mathrm{CLB}_{\mathrm{xy}}$ & (omitted) & $\begin{array}{c}0.343 \\
(0.255)\end{array}$ & (omitted) & $\begin{array}{c}0.333 \\
(0.260)\end{array}$ & (omitted) & $\begin{array}{c}0.329 \\
(0.418)\end{array}$ \\
\hline Crisist & & & $\begin{array}{c}-0.177^{* * * *} \\
(0.060)\end{array}$ & $\begin{array}{l}-0.025 \\
(0.061)\end{array}$ & $\begin{array}{l}-0.738 \\
(0.477)\end{array}$ & $\begin{array}{l}-0.045 \\
(0.102)\end{array}$ \\
\hline Post-crisist & & & $\begin{array}{c}-0.350^{* * * *} \\
(0.116)\end{array}$ & $\begin{array}{l}-0.107 \\
(0.105)\end{array}$ & $\begin{array}{l}-1.144^{*} \\
(0.589)\end{array}$ & $\begin{array}{l}-0.140 \\
(0.125)\end{array}$ \\
\hline$\alpha_{0}$ & $\begin{array}{c}-11.695^{* *} \\
(4.284)\end{array}$ & $\begin{array}{l}-2.955 \\
(3.153)\end{array}$ & $\begin{array}{c}-20.358^{* * * *} \\
(6.820)\end{array}$ & $\begin{array}{l}-5.177 \\
(4.725)\end{array}$ & $\begin{array}{c}-40.244^{* * * *} \\
(7.899)\end{array}$ & $\begin{array}{l}-6.232 \\
(3.538)\end{array}$ \\
\hline $\begin{array}{l}\text { Hausman test } \\
\text { preference }\end{array}$ & \multicolumn{2}{|c|}{ FE $($ Prob $>$ ChiSq $=0.0095)$} & \multicolumn{2}{|c|}{$\mathrm{FE}(\operatorname{Prob}>\mathrm{ChiSq}=0.0062)$} & & \\
\hline R-square & 0.288 & 0.4324 & 0.274 & 0.427 & 0.237 & \\
\hline $\begin{array}{c}\text { No. of } \\
\text { observation }\end{array}$ & \multicolumn{2}{|c|}{825} & \multicolumn{4}{|c|}{825} \\
\hline $\begin{array}{c}\text { Coefficient }) / \\
\text { Wald } \chi^{2}\end{array}$ & $67.71^{* * *}$ & $202.86^{* * *}$ & $52.71^{* * *}$ & $269.81^{* * *}$ & $73.77^{* * *}$ & $330.97^{* * *}$ \\
\hline $\begin{array}{l}\text { Time-fixed } \\
\text { effects test }\end{array}$ & & & & & $18.97^{* * *}$ & \\
\hline Pesaran CD test & & & & & $\begin{array}{c}21.298^{* * * *} \\
\mathrm{ABS}=0.434\end{array}$ & \\
\hline
\end{tabular}

As with the findings from the export analysis, the standard gravity variables are significant and with the expected signs, except for the common land border, which does not 
significantly influence ASEAN imports. Results for the FE model show a significant negative effect of the crisis and post-crisis periods on imports, but the statistical significance of these effects dissipates in the TFE results and vanishes in the HT results, which have superior econometric properties to the FE, RE and TFE estimates. The lack of significant impact of the crisis and its aftermath on import flows in the HT estimates contrasts sharply with the corresponding HT results for the effects on ASEAN exports shown in Table 1, with the estimated coefficients in the import regression being much smaller in magnitude.

Table 4 presents results for intra-ASEAN imports and the extra-ASEAN imports, with Columns 1 to 4 for intra-ASEAN results and Columns 5 and 6 for extra-ASEAN results. The Hausman test prefers the FE estimators for all models. For the intra-ASEAN import models, the time and country fixed effects model is preferred, so results of the time and country fixed effects estimation are presented in Columns 3. Further, the cross-sectional dependence test for the intraASEAN import model suggests the existence of a correlation among the residuals. Hence, we reestimate the model using the HT method and the results are presented in Column 4.

For intra-ASEAN imports, only the TFE results show negative significant effects of the crisis and post-crisis periods, while the other three estimation methods, including the HT method with its superior econometric properties, find those dummies insignificant. ${ }^{14}$ As with the results for intra-ASEAN exports, which are based on the pretty much the opposite side of the same flow, the R-square values are low suggesting there is either substantial random disturbance in the country's exports or that omitted variables have a substantial influence. As a result, the coefficient estimates need to be treated with great caution as is the case with intra-ASEAN exports.

\footnotetext{
${ }^{14}$ The results for intra-ASEAN imports are very similar to those for intra-ASEAN exports as they are largely just the opposite sides of the same trade.
} 
Table 4: Intra- and extra-ASEAN imports

\begin{tabular}{|c|c|c|c|c|c|c|}
\hline & \multicolumn{4}{|c|}{ Crisis dummies included intra-ASEAN model } & \multicolumn{2}{|c|}{ Crisis dummies included extra-ASEAN model } \\
\hline & $\mathrm{FE}$ & $\mathrm{RE}$ & TFE & HT & $\mathrm{FE}$ & $\mathrm{RE}$ \\
\hline & $(1)$ & $(2)$ & (3) & $(4)$ & $(5)$ & $(6)$ \\
\hline $\operatorname{lngdp}_{\mathrm{x}}$ & $\begin{array}{c}2.506 \\
(2.078)\end{array}$ & $\begin{array}{c}0.912^{* * *} \\
(0.177)\end{array}$ & $\begin{array}{c}4.352 \\
(2.612)\end{array}$ & $\begin{array}{l}1.216^{* * *} \\
(0.358)\end{array}$ & $\begin{array}{c}0.655^{\text {**** }} \\
(0.163)\end{array}$ & $\begin{array}{c}0707^{* * *} \\
(0.09)\end{array}$ \\
\hline $\operatorname{lngdp} p_{y}$ & $\begin{array}{c}-0.358 \\
(1.310)\end{array}$ & $\begin{array}{c}0.329 \\
(0.369)\end{array}$ & $\begin{array}{l}1.570^{*} \\
(0.816)\end{array}$ & $\begin{array}{c}0.503 \\
(0.412)\end{array}$ & $\begin{array}{c}0.709^{* * * *} \\
(0.165)\end{array}$ & $\begin{array}{c}0.626^{* * * *} \\
(0.103)\end{array}$ \\
\hline lndistance $_{\mathrm{xy}}$ & (omitted) & $\begin{array}{l}-0.88^{* * * *} \\
(0.249)\end{array}$ & (omitted) & $\begin{array}{c}-0.866^{* * *} \\
(0.431)\end{array}$ & (omitted) & $\begin{array}{l}-0501^{* *} \\
(0.185)\end{array}$ \\
\hline $\mathrm{CLB}_{\mathrm{xy}}$ & (omitted) & $\begin{array}{c}0.178 \\
(0.264)\end{array}$ & (omitted) & $\begin{array}{c}0.123 \\
(0.642)\end{array}$ & & \\
\hline Crisist & $\begin{array}{l}-0.516 \\
(0.331)\end{array}$ & $\begin{array}{l}-0.018 \\
(0.120)\end{array}$ & $\begin{array}{c}-3.137^{* * *} \\
(1.157)\end{array}$ & $\begin{array}{l}-0.265 \\
(0.299)\end{array}$ & $\begin{array}{c}-0.088^{* * *} \\
(0.035)\end{array}$ & $\begin{array}{l}-0.066^{*} \\
(0.039)\end{array}$ \\
\hline Post-crisis ${ }_{t}$ & $\begin{array}{c}-0.876 \\
(0.570)\end{array}$ & $\begin{array}{l}-0.119 \\
(0.209)\end{array}$ & $\begin{array}{c}-5.038^{* * *} \\
(2.004)\end{array}$ & $\begin{array}{c}-0.505 \\
(0.371)\end{array}$ & $\begin{array}{c}-0.194^{* * * *} \\
(0.049)\end{array}$ & $\begin{array}{c}-0.159^{* * * * *} \\
(0.052)\end{array}$ \\
\hline$\alpha_{0}$ & $\begin{array}{l}-33.34^{* *} \\
(20.560)\end{array}$ & $\begin{array}{c}-3.914 \\
(11.655)\end{array}$ & $\begin{array}{c}-129.476^{* * *} \\
(56.367)\end{array}$ & $\begin{array}{l}-16.247 \\
(10.960)\end{array}$ & $\begin{array}{c}-14.641^{* * *} \\
(1.919)\end{array}$ & $\begin{array}{c}-9.607^{* * * * *} \\
(2.229)\end{array}$ \\
\hline $\begin{array}{l}\text { Hausman } \\
\text { test } \\
\text { preference }\end{array}$ & \multicolumn{4}{|c|}{$\mathrm{FE}($ Prob $>\mathrm{ChiSq}=0.033)$} & \multicolumn{2}{|c|}{ FE $($ Prob $>$ ChiSq $=0.0148)$} \\
\hline R-square & 0.104 & 0.225 & 0.0745 & & 0.536 & 0.585 \\
\hline $\begin{array}{c}\text { No. of } \\
\text { observation } \\
\text { F (all }\end{array}$ & \multicolumn{4}{|c|}{275} & \multicolumn{2}{|c|}{550} \\
\hline $\begin{array}{c}\text { coefficient)/ } \\
\text { Wald } \chi^{2}\end{array}$ & $12.74^{* * *}$ & $113.91^{* * *}$ & $23.75^{* * *}$ & $51.30^{* * *}$ & $98.78^{* * *}$ & $500.09^{* * *}$ \\
\hline $\begin{array}{l}\text { Time-fixed } \\
\text { effects test }\end{array}$ & & & $5.89^{* * *}$ & & & \\
\hline $\begin{array}{c}\text { Pesaran CD } \\
\text { Test }\end{array}$ & & & $\begin{array}{c}20.068^{* * *} \\
\mathrm{ABS}=0.488\end{array}$ & & & \\
\hline
\end{tabular}

We estimate the extra-ASEAN import panel using the Hausman-Taylor model (HT), with the results presented in Column 7. The estimated coefficients from the HT model are similar to the estimates from the FE model, and the F-value is large and highly significant. Hence, the HT model provides the preferred results for extra-ASEAN imports, which show ASEAN imports from non-ASEAN countries drop by about $6 \%\left(1-\mathrm{e}^{-0.066}\right)$ during the crisis period and by $15 \%$ (1 - $\mathrm{e}^{-0.159}$ ) during the post-crisis period. As with ASEAN exports, these effects are in addition to whatever changes are due to changes in GDP at home and abroad.

Aside from intra-ASEAN trade, our empirical results demonstrate a significant negative effect of the GFC on ASEAN export trade during both the 2008-2009 crisis period and an even larger effect during the 2010-2012 post-crisis period, which is above and beyond any change due to changes in GDP at home and abroad. Corresponding statistically significant negative effects of the crisis and post-crisis periods on ASEAN import trade are found only for imports from external trading partners. Overall, these results indicate a disadvantage to ASEAN trade flows 
from the GFC and its aftermath, which is consistent with the core-periphery approach to analyzing international trade flows.

\section{Calculation of "Total" Trade Effect}

Now, we look at the "total" effect of the GFC on the five ASEAN economies' trade. The idea behind this calculation is the combination of two generally offsetting effects, the negative coreperiphery effect of crisis and post-crisis coefficients, and the mostly positive effects of the change in the GDP of the home country and their trading partners. Only during the height of the crisis in 2009 did the two effects work in the same direction to reduce trade. After the crisis period, the negative post-crisis coefficient is offset by generally increasing GDP at home and abroad.

Based on the results for estimation by the HT AR(1) method in Column 5 of Table 1 for ASEAN exports and the results from estimation by HT method in Column 6 of Table 3 for imports, trade effects are explained as follows:

$$
\begin{aligned}
& \ln \exp _{x y t}=-6.711+0.598 \ln g d p_{x t}+0.833 \ln g d p_{y t}-1.149 \ln d i s t_{x y}+0.064 C L B_{x y}-0.183 \text { crisis }_{t}-0.304 \text { postcrisis }_{t} \\
& \ln i m p_{x y t}=-6.232+0.781 \ln g d p_{x t}+0.528 \ln g d p_{y t}-0.831 \ln \text { dist }_{x y}+0.329 C L B_{x y}-0.045 \text { crisis }_{t}-0.140 \text { postcrisis }_{t}
\end{aligned}
$$

Plugging in the values of the right-hand-side variables into Equations (5) and (6) returns the value of exports and imports, respectively, in each year. Growth for the GFC period is calculated as the change in exports or imports between 2007 and 2009 and for the post-GFC period as the corresponding change between 2009 and 2012. Because distance, common land borders and the constant term are constant over time, the calculation of change depends only on GDP growth and the crisis or post-crisis effect.

As an example, Indonesian GDP growth in the GFC period is $10.6 \%$ and $18.4 \%$ in the post-GFC period. Australian GDP growth in the GFC period is $5.5 \%$ and $8 \%$ in the post-GFC period. ${ }^{15}$ Hence, the total GFC effect on Indonesia-Australia exports during the crisis period is $(10.6 \% * 0.598+5.5 \% * 0.833-0.183) / 2$ or $-3.67 \%$. Similarly, the total GFC effect on IndonesiaAustralia exports during the post-crisis period is $\left(18.4 \%{ }^{*} 0.598+8 \%{ }^{*} 0.833-0.304\right) / 3$ or $-4.23 \%$. Even though GDP has increased in both Indonesia and Australia during the crisis and post-crisis

\footnotetext{
${ }^{15}$ GDP growth is calculated as percentage change of GDP for the period, with data collected from World Bank database. (Same GDP data has been used for Panel estimation to ensure consistency). Here, GFC period includes 2 years (2008 \& 2009) and post-GFC period includes 3 years (2010-2012).
} 
periods, the calculated "total" effect on Indonesian exports to Australia is negative in both periods due to the extra decrease in trade associated with the dummy variable for each period.

Table 5 presents the results for the calculation of Equation (5), and Table 6 presents corresponding results for Equation (6). These results are presented as annual average changes to adjust for the different lengths of the crisis and post-crisis periods. Referring to Equation (5), both crisis and post-crisis dummies have a significant negative impact on exports, with the effects nearly doubling during the post-GFC period. Beginning with Indonesia, results show that exports to all trading partners aside from China decline during the financial crisis period due to the negative crisis coefficient, as well as the substantial drop in trading partners' GDP that more than offsets the impact of $10 \%$ Indonesian GDP growth. During the post-crisis period, high GDP growth of Indonesia and its trading partners fully offsets the high post-GFC effect only for China and Singapore.

Malaysia, Philippines, Singapore and Thailand have slower growth in domestic GDP than does Indonesia during the crisis period, which makes for a greater negative "total" effect on their exports to all trading partners. Even the Philippines, with the highest growth in domestic GDP among the four countries, experiences a positive "total" effect on their trade only with China. China maintained 5 to 9 per cent average annual growth even during the crisis period (20072009), while average annual growth for other countries was 2 per cent or below, and negative in some cases (Hong Kong, Japan, New Zealand, UAE and USA). Relatively low GDP growth during the crisis period for Malaysia, Singapore and Thailand failed to offset the effect of negative crisis-period coefficient and the low GDP growth of the trading partners, leading to a negative "total" effect on exports to all trading partners. 
Table 5: "Total" GFC and post-GFC effects on ASEAN members' exports

\begin{tabular}{|c|c|c|c|c|c|c|c|c|c|c|}
\hline \multirow{2}{*}{$\begin{array}{c}\text { Reporter } \\
\text { Trading } \\
\text { partners }\end{array}$} & \multicolumn{2}{|c|}{ Indonesia } & \multicolumn{2}{|c|}{ Malaysia } & \multicolumn{2}{|c|}{ Philippines } & \multicolumn{2}{|c|}{ Singapore } & \multicolumn{2}{|c|}{ Thailand } \\
\hline & $\begin{array}{l}\text { Crisis } \\
\text { period }\end{array}$ & $\begin{array}{c}\text { Post- } \\
\text { crisis } \\
\text { period }\end{array}$ & $\begin{array}{l}\text { Crisis } \\
\text { period }\end{array}$ & $\begin{array}{c}\text { Post- } \\
\text { crisis } \\
\text { period }\end{array}$ & $\begin{array}{l}\text { Crisis } \\
\text { period }\end{array}$ & $\begin{array}{c}\text { Post- } \\
\text { crisis } \\
\text { period }\end{array}$ & $\begin{array}{l}\text { Crisis } \\
\text { period }\end{array}$ & $\begin{array}{c}\text { Post- } \\
\text { crisis } \\
\text { period } \\
\end{array}$ & $\begin{array}{l}\text { Crisis } \\
\text { period }\end{array}$ & $\begin{array}{c}\text { Post- } \\
\text { crisis } \\
\text { period } \\
\end{array}$ \\
\hline Australia & $-3.67 \%$ & $-4.24 \%$ & $-6.62 \%$ & $-4.37 \%$ & $-5.27 \%$ & $-4.33 \%$ & $-6.50 \%$ & $-2.86 \%$ & $-6.55 \%$ & $-4.80 \%$ \\
\hline China & $1.97 \%$ & $1.32 \%$ & $-0.98 \%$ & $1.19 \%$ & $0.37 \%$ & $1.23 \%$ & $-0.86 \%$ & $2.70 \%$ & $-0.90 \%$ & $0.76 \%$ \\
\hline Hong Kong & $-6.11 \%$ & $-2.77 \%$ & $-9.05 \%$ & $-2.91 \%$ & $-7.70 \%$ & $-2.86 \%$ & $-8.93 \%$ & $-1.39 \%$ & $-8.98 \%$ & $-3.34 \%$ \\
\hline India & $-0.82 \%$ & $-0.25 \%$ & $-3.76 \%$ & $-0.39 \%$ & $-2.41 \%$ & $-0.34 \%$ & $-3.64 \%$ & $1.12 \%$ & $-3.69 \%$ & $-0.82 \%$ \\
\hline Indonesia & & $-1.35 \%$ & $-4.48 \%$ & $-1.48 \%$ & $-3.13 \%$ & $-1.43 \%$ & $-4.36 \%$ & $0.03 \%$ & $-4.41 \%$ & $-1.91 \%$ \\
\hline Japan & $-8.68 \%$ & $-4.91 \%$ & $-11.62 \%$ & $-5.05 \%$ & $-10.28 \%$ & $-5.00 \%$ & $-11.51 \%$ & $-3.54 \%$ & $-11.55 \%$ & $-5.48 \%$ \\
\hline Malaysia & $-5.64 \%$ & $-1.53 \%$ & & & $-7.23 \%$ & $-1.62 \%$ & $-8.47 \%$ & $-0.15 \%$ & $-8.51 \%$ & $-2.10 \%$ \\
\hline $\begin{array}{c}\text { New } \\
\text { Zealand }\end{array}$ & $-6.56 \%$ & $-4.78 \%$ & $-9.51 \%$ & $-4.92 \%$ & $-8.16 \%$ & $-4.87 \%$ & $-9.39 \%$ & $-3.40 \%$ & $-9.43 \%$ & $-5.35 \%$ \\
\hline Philippines & $-3.76 \%$ & $-1.47 \%$ & $-6.70 \%$ & $-1.60 \%$ & & & $-6.59 \%$ & $-0.09 \%$ & $-6.63 \%$ & $-2.03 \%$ \\
\hline $\begin{array}{c}\text { Saudi } \\
\text { Arabia }\end{array}$ & $-4.22 \%$ & $-0.78 \%$ & $-7.17 \%$ & $-0.92 \%$ & $-5.82 \%$ & $-0.87 \%$ & $-7.05 \%$ & $0.59 \%$ & $-7.10 \%$ & $-1.35 \%$ \\
\hline Singapore & $-5.47 \%$ & $0.57 \%$ & $-8.42 \%$ & $0.44 \%$ & $-7.07 \%$ & $0.48 \%$ & & & $-8.35 \%$ & $0.01 \%$ \\
\hline South Korea & $-4.49 \%$ & $-3.00 \%$ & $-7.44 \%$ & $-3.13 \%$ & $-6.09 \%$ & $-3.09 \%$ & $-7.32 \%$ & $-1.62 \%$ & $-7.37 \%$ & $-3.56 \%$ \\
\hline Thailand & $-5.54 \%$ & $-2.13 \%$ & $-8.48 \%$ & $-2.26 \%$ & $-7.13 \%$ & $-2.22 \%$ & $-8.36 \%$ & $-0.75 \%$ & & \\
\hline $\begin{array}{c}\text { United Arab } \\
\text { Emirates }\end{array}$ & $-6.82 \%$ & $-2.82 \%$ & $-9.77 \%$ & $-2.96 \%$ & $-8.42 \%$ & $-2.91 \%$ & $-9.65 \%$ & $-1.45 \%$ & $-9.69 \%$ & $-3.39 \%$ \\
\hline $\begin{array}{l}\text { United } \\
\text { States of } \\
\text { America }\end{array}$ & $-7.25 \%$ & $-4.70 \%$ & $-10.19 \%$ & $-4.83 \%$ & $-8.84 \%$ & $-4.78 \%$ & $-10.07 \%$ & $-3.32 \%$ & $-10.12 \%$ & $-5.26 \%$ \\
\hline Vietnam & $-1.36 \%$ & $-1.49 \%$ & $-4.31 \%$ & $-1.62 \%$ & $-2.96 \%$ & $-1.58 \%$ & $-4.19 \%$ & $-0.11 \%$ & $-4.23 \%$ & $-2.05 \%$ \\
\hline
\end{tabular}


Table 6: "Total" GFC and post-GFC effects on ASEAN members' imports

\begin{tabular}{|c|c|c|c|c|c|c|c|c|c|c|}
\hline \multirow{2}{*}{$\begin{array}{c}\text { Reporter } \\
\text { Trading } \\
\text { partners }\end{array}$} & \multicolumn{2}{|c|}{ Indonesia } & \multicolumn{2}{|c|}{ Malaysia } & \multicolumn{2}{|c|}{ Philippines } & \multicolumn{2}{|c|}{ Singapore } & \multicolumn{2}{|c|}{ Thailand } \\
\hline & $\begin{array}{l}\text { Crisis } \\
\text { period }\end{array}$ & $\begin{array}{l}\text { Post-crisis } \\
\text { period }\end{array}$ & $\begin{array}{l}\text { Crisis } \\
\text { period }\end{array}$ & $\begin{array}{c}\text { Post-crisis } \\
\text { period }\end{array}$ & $\begin{array}{l}\text { Crisis } \\
\text { period }\end{array}$ & $\begin{array}{c}\text { Post-crisis } \\
\text { period }\end{array}$ & $\begin{array}{l}\text { Crisis } \\
\text { period }\end{array}$ & $\begin{array}{c}\text { Post-crisis } \\
\text { period }\end{array}$ & $\begin{array}{l}\text { Crisis } \\
\text { period }\end{array}$ & $\begin{array}{c}\text { Post-crisis } \\
\text { period }\end{array}$ \\
\hline Australia & $2.71 \%$ & $0.66 \%$ & $0.11 \%$ & $0.54 \%$ & $1.30 \%$ & $0.58 \%$ & $0.21 \%$ & $1.88 \%$ & $0.17 \%$ & $0.16 \%$ \\
\hline China & $8.00 \%$ & $5.87 \%$ & $5.40 \%$ & $5.75 \%$ & $6.59 \%$ & $5.79 \%$ & $5.50 \%$ & $7.09 \%$ & $5.46 \%$ & $5.38 \%$ \\
\hline Hong Kong & $0.43 \%$ & $2.03 \%$ & $-2.17 \%$ & $1.92 \%$ & $-0.98 \%$ & $1.95 \%$ & $-2.07 \%$ & $3.25 \%$ & $-2.11 \%$ & $1.54 \%$ \\
\hline India & $5.39 \%$ & $4.40 \%$ & $2.79 \%$ & $4.28 \%$ & $3.98 \%$ & $4.32 \%$ & $2.89 \%$ & $5.61 \%$ & $2.85 \%$ & $3.90 \%$ \\
\hline Japan & $-1.98 \%$ & $0.03 \%$ & $-4.58 \%$ & $-0.09 \%$ & $-3.39 \%$ & $-0.05 \%$ & $-4.48 \%$ & $1.24 \%$ & $-4.52 \%$ & $-0.47 \%$ \\
\hline Malaysia & $0.87 \%$ & $3.20 \%$ & & & $-0.54 \%$ & $3.12 \%$ & $-1.63 \%$ & $4.41 \%$ & $-1.67 \%$ & $2.70 \%$ \\
\hline New Zealand & $0.00 \%$ & $0.15 \%$ & $-2.60 \%$ & $0.03 \%$ & $-1.41 \%$ & $0.07 \%$ & $-2.49 \%$ & $1.37 \%$ & $-2.53 \%$ & $-0.35 \%$ \\
\hline Philippines & $2.63 \%$ & $3.26 \%$ & $0.03 \%$ & $3.14 \%$ & & & $0.13 \%$ & $4.47 \%$ & $0.09 \%$ & $2.76 \%$ \\
\hline Saudi Arabia & $2.20 \%$ & $3.90 \%$ & $-0.40 \%$ & $3.78 \%$ & $0.79 \%$ & $3.82 \%$ & $-0.30 \%$ & $5.12 \%$ & $-0.34 \%$ & $3.40 \%$ \\
\hline Singapore & $1.02 \%$ & $5.17 \%$ & $-1.58 \%$ & $5.05 \%$ & $-0.39 \%$ & $5.09 \%$ & & & $-1.51 \%$ & $4.67 \%$ \\
\hline Thailand & $0.96 \%$ & $2.64 \%$ & $-1.64 \%$ & $2.52 \%$ & $-0.45 \%$ & $2.56 \%$ & $-1.53 \%$ & $3.85 \%$ & $-1.57 \%$ & $2.14 \%$ \\
\hline $\begin{array}{l}\text { United Arab } \\
\text { Emirates }\end{array}$ & $-0.24 \%$ & $1.99 \%$ & $-2.84 \%$ & $1.87 \%$ & $-1.65 \%$ & $1.91 \%$ & $-2.74 \%$ & $3.20 \%$ & $-2.78 \%$ & $1.49 \%$ \\
\hline $\begin{array}{l}\text { United States } \\
\text { of America }\end{array}$ & $-0.64 \%$ & $0.23 \%$ & $-3.24 \%$ & $0.11 \%$ & $-2.05 \%$ & $0.15 \%$ & $-3.14 \%$ & $1.45 \%$ & $-3.17 \%$ & $-0.27 \%$ \\
\hline Vietnam & $4.88 \%$ & $3.24 \%$ & $2.28 \%$ & $3.12 \%$ & $3.47 \%$ & $3.16 \%$ & $2.38 \%$ & $4.46 \%$ & $2.34 \%$ & $2.74 \%$ \\
\hline
\end{tabular}


During the post-crisis period (2010-2012), all selected countries (ASEAN members and trading partners) experienced positive and relatively large average annual GDP growth. This high growth tends to offset the large negative post-GFC coefficient. However, the "total" effect on exports from Indonesia, Malaysia, Philippines and Thailand is still negative except for exports to China and Singapore, while exports from Singapore are positive only to China, Indonesia, India and Saudi Arabia.

The "total" GFC and post-GFC effects on ASEAN imports (Table 6) are somewhat different from those indicated by the export model. The import model yields insignificant negative coefficients of crisis and post-crisis dummies on ASEAN imports. The magnitude of each coefficient is much smaller than the corresponding coefficient in the export results. Still, for purposes of comparison to the export results in Table 5 we include these insignificant estimates in calculating the "total" effect on ASEAN imports in Table $6 .{ }^{16}$ During the crisis period, all ASEAN countries show a negative "total" effect on imports, except Philippines in its trade with China and Indonesia in its trade with Australia, China, India, Saudi Arabia, South Korea and Vietnam. Yet, during post-crisis period, the "total" effect on imports is generally positive as positive GDP growth at home and abroad more than offsets the negative impact of the post-crisis dummy variable.

Overall, this section confirms that negative GDP growth intensifies the core-periphery effect during the crisis period. However, in the post-crisis positive GDP growth effect is strong enough to offset the prolonged negative core-periphery effect from post-crisis ASEAN trade for at least import flows in most of the ASEAN 5. The "total" effect on export flows remains negative for most of the ASEAN 5 in the post-crisis period, with the general exception of trade with China.

\section{Robustness checks}

We check the robustness of our results by estimating alternative specifications of the models in Table 1 for exports and Table 3 for imports as well as expanding the sample of trading partners and segmenting the data to look at results for specific industries. First, we re-estimate the models using an approach where the crisis and post-crisis dummies of Equation (3) and Equation (4) are

\footnotetext{
${ }^{16}$ Removing the effect of the crisis and post-crisis coefficients adds about $2 \%$ a year to the estimate of the "total effect on imports during the crisis period, while during the post-crisis period the addition is about $5 \%$ a year.
} 
replaced by individual year-specific GFC dummies. The results are presented in Appendix Table 3 for exports and Appendix Table 4 for imports.

The results for ASEAN export flows in Appendix Table 3 are broadly similar to those estimated with the crisis and post-crisis variables in Tables 1 and 2, showing statistically significant negative estimated coefficients for all year dummy variables beyond 2008 aside from the results for the intra-ASEAN export trade. The GFC2009 dummy shows a greater impact than the estimated crisis period effect, which reflects the absence of a strong negative effect on trade in 2008. Also, during the post-crisis period, there is generally some lessening of the negative effect on trade in 2010 before the negative impact increases again and reaches a peak in 2012.

The results for imports in Appendix Table 4 are also broadly similar to corresponding results with crisis and post-crisis variables in Tables 3 and 4. Only the results for imports from extra-ASEAN trading partners have statistically significant estimated coefficients for the year dummy variables, with imports in the preferred RE estimates observed to increase by approximately $8 \%$ in 2008 before declining by $21 \%$ in 2009 and somewhat smaller amounts in subsequent years, which suggests a lagged and persistent effect of the GFC on extra-ASEAN imports.

A further check on the specification of the augmented gravity model is conducted by introducing additional explanatory variables that might be responsible for the deterioration of ASEAN trade flows in the crisis and post-crisis periods. First, the dramatic growth of the Chinese economy has substantially changed trading relationships in Asia, so we add Chinese GDP as an explanatory variable. Second, fluctuations in world industrial production have been found to impact strongly on the price of raw materials relative to finished products in the global supply chain (Bloch and Sapsford, 2000), so we also add a variable measuring world industry production (OECD index of industrial production).

Appendix Table 5 presents the estimated results of the extended model. The Hausman test supports the RE model for both exports and imports. We include HT AR(1) results for exports and HT results for imports as these are the preferred estimation results for exports in Table 1 and imports in Table 3, respectively. In comparison to these preferred results, adding the explanatory variables weakens the negative effect associated with the crisis and post-crisis variables. Indeed, the estimated coefficients for these variables in the import model with HT estimation are both positive. However, both crisis and post-crisis coefficients are found 
insignificant for exports and imports. Chinese GDP is found to have an insignificant effect on exports in the HT AR(1) results for exports and the HT results for imports, while the coefficients for world industrial production are positive and significant in all estimates. Thus, the negative impact on ASEAN exports associated with the crisis and post-crisis variables in Table 1 seemingly reflects their sensitivity to fluctuations in global production, which is consistent with the position of ASEAN economies as suppliers of raw materials and intermediate products according to the core-periphery theory of international trading relations (Bloch and Sapsford, 2000).

A further robustness check involves expanding the sample of trading partners to include the major EU economies, UK, Germany, France, Netherlands, Italy and Spain. The results are shown in Appendix Table 6. When comparing across the same estimation method, the results for are similar to those with the original sample of countries. In particular, all the standard gravity variables have the expected sign and are generally statistically significant, while the crisis and post-crisis coefficients are all negative. One notable difference is that the estimated coefficients for the crisis and post-crisis variables in the HT results for imports in Table 6 are larger in magnitude than the corresponding estimates in Table 3 and they are statistically significant.

A final robustness check is to determine whether the effects on total exports and imports apply equally across various industries within the ASEAN 5 economies. We estimate the augmented gravity equation models from Table 1 for exports and Table 3 for imports using data for separate industries and show results for two very different, but both important, industries, agriculture (UNCOMTRADE database classification SITC $0+1+2-27-28+4$ ) and machinery in Appendix Table 7 and in Appendix Table 8.

Results for both separate industries are similar for the corresponding regressions in Table 1 for exports and Table 3 for imports. However, crisis and post-crisis coefficients for both exports and imports are found to be less negative in the agriculture results in Table 7 than for the corresponding coefficients for total exports and imports in Table 1 and Table 3, respectively. In contrast, the crisis and post-crisis coefficients in the machinery results in Table 8 are more negative than the corresponding coefficients for total exports and imports. For both agriculture and machinery, effects are more negative in the post-crisis period compared to the crisis period, but not all estimated coefficients are statistically significant. 


\section{Conclusion}

We analyze the effects of the Global Financial Crisis (GFC) on trade flows of five major ASEAN economies using an augmented gravity model. The analytical framework used here combines the Keynesian and the core-periphery approaches to understanding the impact of external shocks on developing countries. Our results support both approaches, suggesting that external shocks enter ASEAN trade both through changes in trading partner GDP (Keynesian effect) and as an additional negative effect that occurs even during the recovery of the core economies. Burgess and Connell (2013) make a similar point by saying “.... it is important to note that the GFC is still ongoing ...." (Burgess and Connell, 2013:279).

Our estimate of the "total" effect of the GFC on trade flows of all major ASEAN economies with most trading partners is strongly negative during the crisis period as falling GDP combines with a negative residual effect. During the post-crisis period, there is an even stronger negative residual effect, but rising GDP leads to a positive change in imports for most of the ASEAN economies from most trading partners. However, the estimated "total" effect on exports is still generally negative, which suggests the deterioration in the trading position of ASEAN economies is ongoing in the aftermath of the GFC.

This finding is important for ASEAN policy makers. The highly-interrelated trade and production network within ASEAN and in East Asia creates a self-reinforcing trap for their regional trade in a crisis period. If the shock is extra-regional, the length of the post-shock effect depends a great deal on non-ASEAN trading partners' economic performance and structural changes to the international trading system that disadvantage the periphery. However, ASEAN economies currently enjoy high domestic economic growth, which works well as a recovery mechanism to offset any extra-regional shock. This crisis recovery mechanism is built into ASEAN members' market-oriented intra-regional economic integration process. High real GDP growth of the ASEAN countries induces intra-regional demand every year. This growing intraregional demand partially offsets the crisis-affected slow consumption demand of the nonASEAN market. This demonstrates the importance of maintaining strong economic growth in each of the ASEAN countries to maintaining the trade performance for the group as a whole. 


\section{References:}

Anderson, J. E. (1979). A Theoretical Foundation for the Gravity Equation. American Economic Review 69, 106-16.

Anderson, J. E., \& Wincoop, E. v. (2003). Gravity with Gravitas: A Solution to the Border Puzzle. American Economic Review 93, 170-92.

Anderson, J. E., \& Wincoop, E. v. (2004). Trade Costs. Journal of Economic Literature 42, 691-751.

Arrighi, G., Silver, B. J. \& Brewer, B, D. (2003). Industrial Convergence and the Persistence of the North-South Divide. Studies of Comparative International Development 38, 3-31.

Athukorala, P-C. 2010. Production Networks and Trade Patterns in East Asia: Regionalization or Globalization? $A D B$ Working Paper Series on Regional Economic Integration 56, 1-66.

Baltagi, B. H., Bresson, G., \& Pirotte, A. (2003). Fixed Effects, Random Effects or Hausman-Taylor? A Pretest Estimator. Economics Letters 79, 361-69.

Bergstrand, J. (1985). The Gravity Equation in International Trade: Some Microeconomic Foundations and Empirical Evidence. Review of Economics and Statistics 67, 474-81.

Bergstrand, J. (1989). The Generalized Gravity Equation, Monopolistic Competition, and the Factor-Proportions Theory in International Trade. Review of Economics and Statistics 71, 143-53.

Bloch, H. \& Sapsford, D. (2000). Whither the Terms of Trade? An Elaboration of the Prebisch-Singer Hypothesis. Cambridge Journal of Economics, 24, 461-481.

Burgess, J., \& Connell, J. (2013). The Asia Pacific Region: Leading the Global Recovery Post-GFC? Asia Pacific Business Review 19, 279-85.

Chit, M. M., Rizov, M., \& Willenbockel, D. (2010). Exchange Rate Volatility and Exports: New Empirical Evidence from the Emerging East Asian Economies. World Economy 22, 239-263.

Chor, D., \& Manova, K. (2012). Off the Cliff and Back? Credit Conditions and International Trade during the Global Financial Crisis. Journal of International Economics 87, 117-133.

Eaton, J., \& Kortum, S. (2002). Technology, Geography, and Trade. Econometrica 70, 1741-79.

Egger, P. (2002). An Econometric View on the Estimation of Gravity Models and the Calculation of Trade Potentials. World Economy 25, 297-312.

Engel, C. M., \& Rogers, J. H. (1996). How Wide Is The Border? American Economic Review 86, 1112-25.

Fischer, A. M. (2015). The end of peripheries? On the enduring relevance of structuralism for understanding contemporary global development, Development and Change, 46(4): 700-732.

Frankel, J. A., \& Romer, D. (1999). Does Trade Cause Growth? American Economic Review 89, 379-99.

Hausman, J. A. (1978). Specification Tests in Econometrics. Econometrica 46, 1251-71.

Hausman, J.A., \& Taylor, W.E. (1981). Panel Data and Unobservable Individual Effects. Econometrica 49, $1377-$ 98.

Hong, K., \& Tang, H. C. (2012). Crises in Asia: Recovery and Policy Responses. Journal of Asian Economics 23, 654-668.

Jongwanich, Juthathip. (2010). Determinants of Export Performance in East and Southeast Asia. World Economy 33, 20-41.

Kabir, M. and Salim, R. (2010) Can Gravity Model Explain BIMSTEC's Trade? Journal of Economic Integration, 25: $144-166$.

Kimura, F., \& Lee, H. H. (2006). The Gravity Equation in International Trade in Services. Review of World Economics 142, 92 - 121. 
Kiviet, Jan Frederik, \& Feng, Qu. (2014). Efficiency Gains by Modifying GMM Estimation in Linear Models under Heteroskedasticity. CESifo Working Paper 5088, 1-27.

Kiviet, Jan Frederik, Pleus, Milan, \& Poldermans, Rutger. (2015). Accuracy and Efficiency of Various GMM Inference Techniques in Dynamic Micro Panel Data Models. CESifo Working Paper 5189, 1-57.

Krugman, P. (2009). Revenge of the Glut. New York Times. March 1. (http://www.nytimes.com/2009/03/02/ opinion/02krugman.html?_r=0, accessed on 1 April 2013)

McKibbin, Warwick J., \& Stoeckel, Andrew. (2009). The Global Financial Crisis: Causes and Consequences. Paper presented at the Asian Economic Panel Meeting, Tokyo, September 2009.

Merrouche, Ouarda, \& Nier, Erlend. (2010). What Caused the Global Financial Crisis?-Evidence on the Drivers of Financial Imbalances 1999-2007. IMF Working Paper, WP/10/265.

Pomfret, R., \& Sourdin, P. (2009). Have Asian Trade Agreements Reduced Trade Costs? Journal of Asian Economics 20, 255-68.

Pöyhönen, P. (1963). A Tentative Model for the Volume of Trade between Countries. Weltwirtschaftliches Archiv/Review of World Economics 90 (1): 93-100.

Prebisch, Raul. (1950). The Economic Development of Latin America and its Principal Problems. New York: United Nations.

Pula, B. (2014) Effects of the European Financial and Economic Crisis in Kosovo and the Balkans: Modes of Integration and Transmission Belts of Crisis in the "Super-Periphery". East European Politics, 30: 507525.

Rana, P. B. (2007). Economic Integration and Synchronization of Business Cycles in East Asia. Journal of Asian Economics 18, 711-25.

Richardson, M. (2005). Australia-Southeast Asia Relations and the East Asian Summit. Australian Journal of International Affairs 59, 351-65.

Sally, R., \& Sen, R. (2005). Whither Trade Policies in Southeast Asia? The Wider Asian and Global Context. ASEAN Economic Bulletin 22, 92-115.

Sheng, Y., Tang, H. C., \& Xu, X. (2014). The Impact of the ACFTA on ASEAN-PRC Trade: Estimates Based on an Extended Gravity Model for Component Trade. Applied Economics 46, 2251-63.

Shepherd, B. (2013). The Gravity Model of International Trade: A User Guide. Bangkok: ESCAP, United Nations.

Söderbom, Måns, Teal, Francis, Eberhardt, Markus, Quinn, Simon, \& Zeitlin, Andrew. (2015). Empirical Development Economics. NewYork: Routledge.

Stock, James H., Wright, Jonathan H., \& Yogo, Motohiro. (2002). A Survey of Weak Instruments and Weak Identification in Generalized Method of Moments. Journal of Business \& Economic Statistics 20, 518-529.

Tinbergen, J. (1962). Shaping the World Economy-Suggestions for an International Economic Policy. New York: The Twentieth Century Fund.

Wallerstein, I. (1979). The Capitalist World Economy. Cambridge: Cambridge University Press.

Wang, J., \& Whalley, J. (2010). The Trade Performance of Asian Economies During and Following the 2008 Financial Crisis. National Bureau of Economic Research, Working Paper 16142, 1-35. 


\section{Appendix}

Appendix Table 1: Organization of the country panel

\begin{tabular}{|c|c|c|c|c|c|}
\hline \multirow{4}{*}{$\begin{array}{l}\text { Reporter } \\
\text { Trading } \\
\text { partners }\end{array}$} & \multicolumn{5}{|c|}{ Exports and Imports } \\
\hline & Indonesia & Malaysia & Philippines & Singapore & Thailand \\
\hline & Australia & Australia & Australia & Australia & Australia \\
\hline & China & China & China & China & China \\
\hline & Hong Kong & Hong Kong & Hong Kong & Hong Kong & Hong Kong \\
\hline & India & India & India & India & India \\
\hline & Japan & Indonesia & Indonesia & Indonesia & Indonesia \\
\hline & Malaysia & Japan & Japan & Japan & Japan \\
\hline & New Zealand & New Zealand & Malaysia & Malaysia & Malaysia \\
\hline & Philippines & Philippines & New Zealand & New Zealand & New Zealand \\
\hline & Saudi Arabia & Saudi Arabia & Saudi Arabia & Philippines & Philippines \\
\hline & Singapore & Singapore & Singapore & Saudi Arabia & Saudi Arabia \\
\hline & South Korea & South Korea & South Korea & South Korea & Singapore \\
\hline & Thailand & Thailand & Thailand & Thailand & South Korea \\
\hline & United Arab & United Arab & United Arab & United Arab & United Arab \\
\hline & Emirates & Emirates & Emirates & Emirates & Emirates \\
\hline & United States & United States & United States & United States & United States \\
\hline & Vietnam & Vietnam & Vietnam & Vietnam & Vietnam \\
\hline
\end{tabular}


Appendix Table 2: ASEAN trade by partner country, 2011 (as of November 2012)

\begin{tabular}{|c|c|c|c|c|c|c|c|}
\hline \multirow[b]{2}{*}{$\begin{array}{l}\text { ISO } \\
\text { Code }\end{array}$} & \multirow[b]{2}{*}{$\begin{array}{l}\text { Trade partner } \\
\text { country }\end{array}$} & \multicolumn{3}{|c|}{ Value of trade (in US\$ thousand) } & \multicolumn{3}{|c|}{ Share of total (as a \%age) } \\
\hline & & $\begin{array}{l}\text { Exports from } \\
\text { ASEAN }\end{array}$ & $\begin{array}{l}\text { Imports by } \\
\text { ASEAN }\end{array}$ & Total trade & $\begin{array}{l}\text { Exports } \\
\text { from } \\
\text { ASEAN }\end{array}$ & $\begin{array}{c}\text { Imports } \\
\text { by } \\
\text { ASEAN }\end{array}$ & $\begin{array}{l}\text { Total } \\
\text { trade }\end{array}$ \\
\hline $\mathrm{CN}$ & China & $127,908,473.6$ & $152,497,073.0$ & $280,405,546.5$ & 10.3 & 13.3 & 11.7 \\
\hline JP & Japan & $145,197,715.2$ & $128,149,352.1$ & $273,347,067.3$ & 11.7 & 11.2 & 11.4 \\
\hline US & $\begin{array}{l}\text { United States } \\
\text { of America }\end{array}$ & $106,305,608.9$ & $92,480,307.6$ & $198,785,916.5$ & 8.6 & 8.1 & 8.3 \\
\hline SG & Singapore & $94,756,931.4$ & $77,173,522.3$ & $171,930,453.7$ & 7.6 & 6.7 & 7.2 \\
\hline MY & Malaysia & $75,798,397.4$ & $70,584,648$ & $146,383,044.9$ & 6.1 & 6.2 & 6.1 \\
\hline KR & South Korea & $54,467,989.6$ & $70,002,911.9$ & $124,470,901.5$ & 4.4 & 6.1 & 5.2 \\
\hline ID & Indonesia & $59,155,264.1$ & $43,494,586.6$ & $102,649,850.8$ & 4.8 & 3.8 & 4.3 \\
\hline HK & Hong Kong & $81,312,851.0$ & $15,402,084.2$ & $96,714,935.2$ & 6.5 & 1.3 & 4.0 \\
\hline $\mathrm{TH}$ & Thailand & $40,695,909.4$ & $48,012,261.8$ & $88,708,171.2$ & 3.3 & 4.2 & 3.7 \\
\hline IN & India & $42,754,703.5$ & $25,674,078.1$ & $68,428,781.5$ & 3.4 & 2.2 & 2.9 \\
\hline $\mathrm{AU}$ & Australia & $37,253,936.2$ & $22,220,465.8$ & $59,474,402.0$ & 3.0 & 1.9 & 2.5 \\
\hline $\mathrm{AE}$ & $\begin{array}{l}\text { United Arab } \\
\text { Emirates }\end{array}$ & $13,770,477.0$ & $31,356,430.7$ & $45,126,907.7$ & 1.1 & 2.7 & 1.9 \\
\hline SA & Saudi Arabia & $4,513,017.5$ & $36,186,266.5$ & $40,699,284.0$ & 0.4 & 3.2 & 1.7 \\
\hline $\mathrm{VN}$ & Viet Nam & $22,365,208$ & $11,475,478.1$ & $33,840,686.2$ & 1.8 & 1.0 & 1.4 \\
\hline $\mathrm{PH}$ & Philippines & $18,429,032.1$ & $12,123,805$ & $30,552,836.7$ & 1.5 & 1.1 & 1.3 \\
\hline $\mathrm{NZ}$ & New Zealand & $4,569,261.6$ & $3,667,474$ & $8,236,735.9$ & 0.4 & 0.3 & 0.3 \\
\hline $\begin{array}{r}\text { Total A } \\
16 \text { sel }\end{array}$ & $\begin{array}{l}\text { EAN trade with } \\
\text { ted countries }\end{array}$ & $929,254,776.4$ & $840,500,745.0$ & $1,769,755,521.4$ & 74.8 & 73.3 & 74.1 \\
\hline
\end{tabular}




\begin{tabular}{|c|c|c|c|c|c|c|c|c|c|}
\hline & \multicolumn{3}{|c|}{ Total imports } & \multicolumn{3}{|c|}{ Intra-ASEAN model } & \multicolumn{3}{|c|}{ Extra-ASEAN model } \\
\hline & $\begin{array}{l}\mathrm{FE} \\
(1) \\
\end{array}$ & $\begin{array}{l}\mathrm{RE} \\
(2) \\
\end{array}$ & $\begin{array}{c}\text { HT AR (1) } \\
\text { (3) } \\
\end{array}$ & $\begin{array}{l}\mathrm{FE} \\
(4) \\
\end{array}$ & $\begin{array}{l}\mathrm{RE} \\
(5) \\
\end{array}$ & $\begin{array}{l}\text { HT } \\
(6) \\
\end{array}$ & $\begin{array}{l}\text { FE } \\
(7) \\
\end{array}$ & $\begin{array}{l}\mathrm{RE} \\
(8)\end{array}$ & $\begin{array}{c}\text { HT AR (1) } \\
\text { (9) }\end{array}$ \\
\hline $\operatorname{lngdp} x$ & $\begin{array}{c}0.456^{\text {*** }} \\
(0.107)\end{array}$ & $\begin{array}{c}0.627^{* * * *} \\
(0.148)\end{array}$ & $\begin{array}{l}0.625^{\text {*** }} \\
(0.168)\end{array}$ & $\begin{array}{c}-0.864 \\
(1.282)\end{array}$ & $\begin{array}{c}-0.789^{* *} \\
(0.349)\end{array}$ & $\begin{array}{r}0.663 \\
(0.507)\end{array}$ & $\begin{array}{c}0.475^{\text {**** }} \\
(0.093)\end{array}$ & $\begin{array}{c}0.471^{\text {**** }} \\
(0.087)\end{array}$ & $\begin{array}{l}0.471^{\text {**** }} \\
(0.079)\end{array}$ \\
\hline $\operatorname{lngdp} p_{y}$ & $\begin{array}{l}1.034^{* * *} \\
(0.345)\end{array}$ & $\begin{array}{c}0.834^{* * *} \\
(0.092)\end{array}$ & $\begin{array}{l}0.836^{* * *} \\
(0.110)\end{array}$ & $\begin{array}{c}3.009 \\
(2.136)\end{array}$ & $\begin{array}{l}0.600^{* *} \\
(0.291)\end{array}$ & $\begin{array}{l}1.239^{* * *} \\
(0.462)\end{array}$ & $\begin{array}{c}0.761^{* * *} \\
(0.103)\end{array}$ & $\begin{array}{l}0.77^{* * *} \\
(0.090)\end{array}$ & $\begin{array}{c}0.770^{* * * *} \\
(0.090)\end{array}$ \\
\hline lndistance $_{x y}$ & (omitted) & $\begin{array}{c}-1.151^{* * *} \\
(0.128)\end{array}$ & $\begin{array}{c}-1.152^{* * * *} \\
(0.120)\end{array}$ & (omitted) & $\begin{array}{c}-1.167^{* * *} \\
(0.197)\end{array}$ & $\begin{array}{l}-1.110^{*} \\
(0.606)\end{array}$ & (omitted) & $\begin{array}{c}-0.999^{* * * *} \\
(0.246)\end{array}$ & $\begin{array}{c}-0.999^{* * * *} \\
(0.272)\end{array}$ \\
\hline $\mathrm{CLB}_{\mathrm{xy}}$ & (omitted) & $\begin{array}{c}0.06 \\
(0.286)\end{array}$ & $\begin{array}{r}0.060 \\
(0.283)\end{array}$ & (omitted) & $\begin{array}{l}-0.014 \\
(0.257)\end{array}$ & $\begin{array}{r}-0.048 \\
(0.902)\end{array}$ & (omitted) & (omitted) & (omitted) \\
\hline GFC2008 & $\begin{array}{l}-0.121^{*} \\
(0.069)\end{array}$ & $\begin{array}{l}-0.120^{* *} \\
(0.059)\end{array}$ & $\begin{array}{l}-0.120^{*} \\
(0.069)\end{array}$ & $\begin{array}{l}-0.531 \\
(0.355)\end{array}$ & $\begin{array}{l}-0.097 \\
(0.148)\end{array}$ & $\begin{array}{r}-0.369 \\
(0.372)\end{array}$ & $\begin{array}{l}-0.007 \\
(0.031)\end{array}$ & $\begin{array}{l}-0.008 \\
(0.031)\end{array}$ & $\begin{array}{l}-0.008 \\
(0.027)\end{array}$ \\
\hline GFC2009 & $\begin{array}{c}-0.271^{* * *} \\
(0.066)\end{array}$ & $\begin{array}{c}-0.274^{* * *} \\
(0.061)\end{array}$ & $\begin{array}{c}-0.274^{* * * *} \\
(0.073)\end{array}$ & $\begin{array}{l}-0.719^{*} \\
(0.385)\end{array}$ & $\begin{array}{l}-0.257^{*} \\
(0.153)\end{array}$ & $\begin{array}{r}-0.533 \\
(0.370)\end{array}$ & $\begin{array}{c}-0.161^{* * *} \\
(0.042)\end{array}$ & $\begin{array}{c}-0.162^{* * * *} \\
(0.042)\end{array}$ & $\begin{array}{c}-0.162^{* * *} \\
(0.039)\end{array}$ \\
\hline GFC2010 & $\begin{array}{l}-0.249^{* *} \\
(0.105)\end{array}$ & $\begin{array}{c}-0.254^{* * *} \\
(0.094)\end{array}$ & $\begin{array}{l}-0.254^{* *} \\
(0.108)\end{array}$ & $\begin{array}{l}-0.764 \\
(0.533)\end{array}$ & $\begin{array}{l}-0.207 \\
(0.228)\end{array}$ & $\begin{array}{r}-0.567 \\
(0.423)\end{array}$ & $\begin{array}{c}-0.112^{* *} \\
(0.043)\end{array}$ & $\begin{array}{c}-0.114^{* * * *} \\
(0.042)\end{array}$ & $\begin{array}{c}-0.114^{* * *} \\
(0.039)\end{array}$ \\
\hline GFC2011 & $\begin{array}{c}-0.332^{* *} \\
(0.139)\end{array}$ & $\begin{array}{c}-0.332^{* * *} \\
(0.119)\end{array}$ & $\begin{array}{l}-0.332^{* *} \\
(0.140)\end{array}$ & $\begin{array}{l}-0.953 \\
(0.659)\end{array}$ & $\begin{array}{l}-0.288 \\
(0.282)\end{array}$ & $\begin{array}{r}-0.716 \\
(0.467)\end{array}$ & $\begin{array}{c}-0.155^{* * *} \\
(0.048)\end{array}$ & $\begin{array}{c}-0.157^{* * *} \\
(0.047)\end{array}$ & $\begin{array}{c}-0.158^{* * * *} \\
(0.046)\end{array}$ \\
\hline GFC2012 & $\begin{array}{c}-0.395^{* *} \\
(0.156)\end{array}$ & $\begin{array}{c}-0.395^{* * *} \\
(0.133)\end{array}$ & $\begin{array}{l}-0.396^{* *} \\
(0.158)\end{array}$ & $\begin{array}{l}-1.113 \\
(0.746)\end{array}$ & $\begin{array}{l}-0.362 \\
(0.327)\end{array}$ & $\begin{array}{l}-0.836^{*} \\
(0.494)\end{array}$ & $\begin{array}{c}-0.194^{* * *} \\
(0.052)\end{array}$ & $\begin{array}{c}-0.196^{* * *} \\
(0.051)\end{array}$ & $\begin{array}{c}-0.196^{* * *} \\
(0.042)\end{array}$ \\
\hline$\alpha_{0}$ & $\begin{array}{c}-17.806^{* * *} \\
(7.380)\end{array}$ & $\begin{array}{l}-7.442 \\
(5.240)\end{array}$ & $\begin{array}{r}-7.442 \\
(6.276)\end{array}$ & $\begin{array}{l}-32.986 \\
(22.679)\end{array}$ & $\begin{array}{c}-5.472 \\
(12.953)\end{array}$ & $\begin{array}{c}-18.917 \\
(12.140)\end{array}$ & $\begin{array}{c}-11.468^{* * *} \\
(1.972)\end{array}$ & $\begin{array}{l}-3.019 \\
(2.930)\end{array}$ & $\begin{array}{l}-3.024 \\
(3.089)\end{array}$ \\
\hline $\begin{array}{l}\text { Hausman test } \\
\text { preference }\end{array}$ & \multicolumn{3}{|c|}{ RE $($ Prob $>$ ChiSq $=0.983)$} & \multicolumn{3}{|c|}{ RE $($ Prob $>$ ChiSq $=0.1487)$} & \multicolumn{3}{|c|}{ RE $($ Prob $>$ ChiSq $=0.9991)$} \\
\hline R-square & 0.221 & 0.455 & & 0.03 & 0.246 & & 0.472 & 0.581 & \\
\hline $\begin{array}{l}\text { No. of } \\
\text { observation } \\
\text { F (all } \\
\text { coefficient)/ } \\
\text { Wald } \chi^{2}\end{array}$ & $65.9^{* * * *}$ & $778.29^{* * *}$ & $857.94^{* * * *}$ & $14.22^{* * *}$ & $353.34^{* * *}$ & $44.09^{* * * *}$ & $71.06^{* * * *}$ & $615.12^{* * *}$ & $721.45^{* * *}$ \\
\hline
\end{tabular}


Appendix Table 4: Estimation results for ASEAN imports (crisis and post-crisis dummies are replaced by year-specific GFC dummies)

\begin{tabular}{|c|c|c|c|c|c|c|c|c|}
\hline & \multicolumn{3}{|c|}{ Total imports model } & \multicolumn{3}{|c|}{ Intra-ASEAN model } & \multicolumn{2}{|c|}{ Extra-ASEAN model } \\
\hline & $\begin{array}{l}\mathrm{FE} \\
(1)\end{array}$ & $\begin{array}{l}\mathrm{RE} \\
(2)\end{array}$ & $\begin{array}{l}\text { HT } \\
\text { (3) }\end{array}$ & $\begin{array}{l}\mathrm{FE} \\
(4)\end{array}$ & $\begin{array}{l}\mathrm{RE} \\
(5)\end{array}$ & $\begin{array}{l}\text { HT } \\
(6)\end{array}$ & $\begin{array}{l}\mathrm{FE} \\
(7)\end{array}$ & $\begin{array}{l}\mathrm{RE} \\
(8)\end{array}$ \\
\hline $\operatorname{lngdp} p_{x}$ & $\begin{array}{l}0.883^{\text {*** }} \\
(0.364)\end{array}$ & $\begin{array}{c}0.775^{\text {**** }} \\
(0.071)\end{array}$ & $\begin{array}{l}0.781^{\text {**** }} \\
(0.071)\end{array}$ & $\begin{array}{c}2.603 \\
(2.217)\end{array}$ & $\begin{array}{c}0.921^{\text {**** }} \\
(0.179)\end{array}$ & $\begin{array}{l}1.267^{\text {***** }} \\
(0.370)\end{array}$ & $\begin{array}{c}0.636^{\text {**** }} \\
(0.163)\end{array}$ & $\begin{array}{c}0.694^{\text {***** }} \\
(0.092)\end{array}$ \\
\hline $\operatorname{lngdp} p_{y}$ & $\begin{array}{c}0.737^{* * * *} \\
(0.166)\end{array}$ & $\begin{array}{l}0.499^{* * * *} \\
(0.153)\end{array}$ & $\begin{array}{l}0.540^{* * * *} \\
(0.140)\end{array}$ & $\begin{array}{l}-0.338 \\
(1.295)\end{array}$ & $\begin{array}{c}0.342 \\
(0.379)\end{array}$ & $\begin{array}{r}0.541 \\
(0.425)\end{array}$ & $\begin{array}{c}0.723^{* * *} \\
(0.166)\end{array}$ & $\begin{array}{c}0.634^{* * * *} \\
(0.106)\end{array}$ \\
\hline lndistance $_{\mathrm{xy}}$ & (omitted) & $\begin{array}{c}-0.824^{* * * *} \\
(0.116)\end{array}$ & $\begin{array}{l}-0.832^{* * * *} \\
(0.143)\end{array}$ & (omitted) & $\begin{array}{l}-0.88^{* * * *} \\
(0.251)\end{array}$ & $\begin{array}{l}-0.864^{*} \\
(0.449)\end{array}$ & (omitted) & $\begin{array}{c}-0.492^{* * * *} \\
(0.186)\end{array}$ \\
\hline $\operatorname{CLB}_{\mathrm{xy}}$ & (omitted) & $\begin{array}{c}0.332 \\
(0.261)\end{array}$ & $\begin{array}{c}0.327 \\
(0.421)\end{array}$ & (omitted) & $\begin{array}{c}0.176 \\
(0.267)\end{array}$ & $\begin{array}{c}0.113 \\
(0.668)\end{array}$ & (omitted) & (omitted) \\
\hline GFC2008 & $\begin{array}{l}-0.066 \\
(0.071)\end{array}$ & $\begin{array}{l}-0.101 \\
(0.067)\end{array}$ & $\begin{array}{r}0.077 \\
(0.124)\end{array}$ & $\begin{array}{l}-0.473 \\
(0.351)\end{array}$ & $\begin{array}{c}0.068 \\
(0.124)\end{array}$ & $\begin{array}{l}-0.214 \\
(0.259)\end{array}$ & $\begin{array}{c}-0.06 \\
(0.038)\end{array}$ & $\begin{array}{l}0.082^{* *} \\
(0.042)\end{array}$ \\
\hline GFC2009 & $\begin{array}{c}-0.317^{* * * *} \\
(0.065)\end{array}$ & $\begin{array}{l}-0.157^{* *} \\
(0.064)\end{array}$ & $\begin{array}{r}-0.180 \\
(0.123)\end{array}$ & $\begin{array}{l}-0.681^{*} \\
(0.381)\end{array}$ & $\begin{array}{l}-0.126 \\
(0.128)\end{array}$ & $\begin{array}{r}-0.407 \\
(0.358)\end{array}$ & $\begin{array}{c}-0.236^{* * * *} \\
(0.039)\end{array}$ & $\begin{array}{c}-0.211^{* * * *} \\
(0.042)\end{array}$ \\
\hline GFC2010 & $\begin{array}{c}-0.312^{* * * *} \\
(0.099)\end{array}$ & $\begin{array}{c}-0.09 \\
(0.090)\end{array}$ & $\begin{array}{r}-0.122 \\
(0.139)\end{array}$ & $\begin{array}{l}-0.758 \\
(0.515)\end{array}$ & $\begin{array}{l}-0.047 \\
(0.181)\end{array}$ & $\begin{array}{r}-0.423 \\
(0.407)\end{array}$ & $\begin{array}{c}-0.195^{* * * *} \\
(0.043)\end{array}$ & $\begin{array}{c}-0.163^{* * *} \\
(0.045)\end{array}$ \\
\hline GFC2011 & $\begin{array}{c}-0.373^{* * * *} \\
(0.136)\end{array}$ & $\begin{array}{l}-0.106 \\
(0.116)\end{array}$ & $\begin{array}{r}-0.144 \\
(0.151)\end{array}$ & $\begin{array}{l}-1.005 \\
(0.638)\end{array}$ & $\begin{array}{l}-0.156 \\
(0.229)\end{array}$ & $\begin{array}{r}-0.605 \\
(0.446)\end{array}$ & $\begin{array}{c}-0.173^{* * * *} \\
(0.055)\end{array}$ & $\begin{array}{c}-0.138^{* * *} \\
(0.057)\end{array}$ \\
\hline GFC2012 & $\begin{array}{c}-0.433^{\text {**** }} \\
(0.153)\end{array}$ & $\begin{array}{l}-0.142 \\
(0.131)\end{array}$ & $\begin{array}{r}-0.184 \\
(0.159)\end{array}$ & $\begin{array}{l}-1.151 \\
(0.722)\end{array}$ & $\begin{array}{l}-0.207 \\
(0.256)\end{array}$ & $\begin{array}{r}-0.701 \\
(0.471)\end{array}$ & $\begin{array}{c}-0.213^{* * * *} \\
(0.066)\end{array}$ & $\begin{array}{c}-0.173^{* * *} \\
(0.070)\end{array}$ \\
\hline$\alpha_{0}$ & $\begin{array}{c}-21.08^{* * *} \\
(7.220)\end{array}$ & $\begin{array}{l}-5.347 \\
(4.911)\end{array}$ & $\begin{array}{l}-6.527^{*} \\
(3.614)\end{array}$ & $\begin{array}{l}-36.331 \\
(22.239)\end{array}$ & $\begin{array}{c}-4.468 \\
(11.997)\end{array}$ & $\begin{array}{l}-18.524^{*} \\
(11.089)\end{array}$ & $\begin{array}{c}-14.477^{* * * *} \\
(1.975)\end{array}$ & $\begin{array}{c}-9.554^{* * *} \\
(2.290)\end{array}$ \\
\hline $\begin{array}{l}\text { Hausman test } \\
\text { preference }\end{array}$ & \multicolumn{2}{|c|}{$\mathrm{FE}($ Prob $>$ ChiSq $=0.0384)$} & & \multicolumn{2}{|c|}{$\mathrm{RE}(\mathrm{Prob}>\mathrm{ChiSq}=0.1262)$} & & \multicolumn{2}{|c|}{$\mathrm{RE}($ Prob $>\mathrm{ChiSq}=0.0702)$} \\
\hline R-square & 0.274 & 0.428 & & 0.1038 & 0.2255 & & 0.533 & 0.585 \\
\hline $\begin{array}{c}\text { No. of } \\
\text { observation } \\
\text { F (all } \\
\text { coefficient)/ } \\
\text { Wald } \chi^{2}\end{array}$ & $59.06^{* * *}$ & $507.67^{* * *}$ & $334.53^{* * *}$ & $17.72^{* * * *}$ & $202.00^{* * *}$ & & $66.43^{* * * *}$ & $574.37^{* * *}$ \\
\hline
\end{tabular}

Note: ${ }^{* * * * *}$ and ${ }^{*}$ denote $1 \%, 5 \%$ and $10 \%$ levels of significance, respectively 
Appendix Table 5: Robustness check for additional control variables

\begin{tabular}{|c|c|c|c|c|c|c|}
\hline & \multicolumn{3}{|c|}{ Export } & \multicolumn{3}{|c|}{ Imports } \\
\hline & $\begin{array}{l}\mathrm{FE} \\
\text { (1) }\end{array}$ & $\begin{array}{l}\mathrm{RE} \\
\text { (2) }\end{array}$ & $\begin{array}{c}\mathrm{AR}(1) \mathrm{HT} \\
\text { (3) }\end{array}$ & $\begin{array}{l}\text { FE } \\
\text { (4) }\end{array}$ & $\begin{array}{l}\text { RE } \\
\text { (5) }\end{array}$ & $\begin{array}{l}\text { HT } \\
\text { (6) }\end{array}$ \\
\hline $\operatorname{lngdp_{x}}$ & $\begin{array}{c}0.215 \\
(0.409)\end{array}$ & $\begin{array}{l}0.521^{\text {*** }} \\
(0.212)\end{array}$ & $\begin{array}{c}0.518^{* * * *} \\
(0.176)\end{array}$ & $\begin{array}{c}0.999^{* * * *} \\
(0.309)\end{array}$ & $\begin{array}{c}0.732^{* * * *} \\
(0.059)\end{array}$ & $\begin{array}{c}0.756^{* * * *} \\
(0.084)\end{array}$ \\
\hline $\operatorname{lngdp} p_{y}$ & $\begin{array}{c}0.987^{* * * *} \\
(0.297)\end{array}$ & $\begin{array}{c}0.821^{* * * *} \\
(0.084)\end{array}$ & $\begin{array}{c}0.822^{* * * *} \\
(0.101)\end{array}$ & $\begin{array}{c}1.374^{* * * *} \\
(0.458)\end{array}$ & $\begin{array}{l}0.134^{* *} \\
(0.168)\end{array}$ & $\begin{array}{c}0.302 \\
(0.249)\end{array}$ \\
\hline lndistance $_{\mathrm{xy}}$ & (omitted) & $\begin{array}{c}-1.114^{* * * *} \\
(0.143)\end{array}$ & $\begin{array}{c}-1.135^{* * * *} \\
(0.145)\end{array}$ & (omitted) & $\begin{array}{c}-0.767^{* * * *} \\
(0.122)\end{array}$ & $\begin{array}{c}-0.797^{* * * *} \\
(0.171)\end{array}$ \\
\hline $\mathrm{CLB}_{\mathrm{xy}}$ & (omitted) & $\begin{array}{c}0.073 \\
(0.285)\end{array}$ & $\begin{array}{c}0.074 \\
(0.236)\end{array}$ & (omitted) & $\begin{array}{c}0.375 \\
(0.242)\end{array}$ & $\begin{array}{c}0.356 \\
(0.497)\end{array}$ \\
\hline Crisist & $\begin{array}{c}-0.037 \\
(0.155)\end{array}$ & $\begin{array}{l}-0.041 \\
(0.089)\end{array}$ & $\begin{array}{l}-0.041 \\
(0.092)\end{array}$ & $\begin{array}{l}-0.128 \\
(0.089)\end{array}$ & $\begin{array}{l}-0.102 \\
(0.096)\end{array}$ & $\begin{array}{c}0.105 \\
(0.169)\end{array}$ \\
\hline Post-crisist & $\begin{array}{l}-0.115 \\
(0.155)\end{array}$ & $\begin{array}{l}-0.124 \\
(0.166)\end{array}$ & $\begin{array}{l}-0.124 \\
(0.175)\end{array}$ & $\begin{array}{l}-0.045 \\
(0.154)\end{array}$ & $\begin{array}{l}-0.032 \\
(0.169)\end{array}$ & $\begin{array}{c}0.033 \\
(0.217)\end{array}$ \\
\hline lnchinesegdp & $\begin{array}{l}-0.015 \\
(0.289)\end{array}$ & $\begin{array}{l}-0.124 \\
(0.259)\end{array}$ & $\begin{array}{l}-0.115 \\
(0.229)\end{array}$ & $\begin{array}{c}-0.856^{* * * *} \\
(0.306)\end{array}$ & $\begin{array}{c}0.101 \\
(0.223)\end{array}$ & $\begin{array}{l}-0.021 \\
(0.252)\end{array}$ \\
\hline industrialproduction & $\begin{array}{c}0.013^{* * *} \\
(0.003)\end{array}$ & $\begin{array}{l}0.012^{\text {**** }} \\
(0.003)\end{array}$ & $\begin{array}{l}0.012^{* * * *} \\
(0.002)\end{array}$ & $\begin{array}{c}0.012^{* * * *} \\
(0.003)\end{array}$ & $\begin{array}{l}0.022^{* * *} \\
(0.003)\end{array}$ & $\begin{array}{l}0.020^{* * *} \\
(0.009)\end{array}$ \\
\hline$\alpha_{0}$ & $\begin{array}{c}-11.206 \\
(5.687)\end{array}$ & $\begin{array}{l}-2.434 \\
(5.313)\end{array}$ & $\begin{array}{c}-2.414 \\
(5.918)\end{array}$ & $\begin{array}{c}-17.482^{* * * *} \\
(5.551)\end{array}$ & $\begin{array}{l}-0.316 \\
(5.501)\end{array}$ & $\begin{array}{l}-1.430 \\
(5.053)\end{array}$ \\
\hline Hausman test preference & \multicolumn{2}{|c|}{$\operatorname{RE}($ Prob $>$ ChiSq $=0.957)$} & & \multicolumn{2}{|c|}{ RE $($ Prob $>$ ChiSq $=0.0799)$} & \\
\hline R-sq & 0.219 & 0.454 & & 0.039 & 0.451 & \\
\hline No. of observation & & 825 & & & 825 & \\
\hline $\mathrm{F}$ (all coefficient)/ Wald $\chi^{2}$ & $93.45^{* * *}$ & $919.20^{* * *}$ & $973.02^{* * *}$ & $84.74^{* * *}$ & $650.22^{* * * *}$ & $346.15^{* * *}$ \\
\hline
\end{tabular}


Appendix Table 6: Estimation results for panel with EU countries included

\begin{tabular}{|c|c|c|c|c|c|c|}
\hline & \multicolumn{3}{|c|}{ Export } & \multicolumn{3}{|c|}{ Imports } \\
\hline & $\overline{\mathrm{FE}}$ & $\mathrm{RE}$ & HT AR (1) & $\overline{\mathrm{FE}}$ & $\mathrm{RE}$ & HT \\
\hline & (1) & (2) & (3) & (4) & (5) & (6) \\
\hline \multirow[t]{2}{*}{$\operatorname{lngdp}_{x}$} & $0.356^{* *}$ & $0.514^{* * * *}$ & $0.512^{* * * *}$ & $0.814^{* * * *}$ & $0.797^{* * * *}$ & $0.814^{* * * *}$ \\
\hline & $(0.149)$ & $(0.112)$ & (0.099) & $(0.127)$ & $(0.061)$ & $(0.217)$ \\
\hline \multirow[t]{2}{*}{$\operatorname{lngdp} y$} & $0.996^{* * * *}$ & $0.818^{* * *}$ & $0.819^{* * *}$ & $0.637^{* * * *}$ & $0.458^{* * * *}$ & $0.637^{* * *}$ \\
\hline & $(0.127)$ & $(0.072)$ & $(0.086)$ & $(0.149)$ & $(0.104)$ & $(0.149)$ \\
\hline \multirow[t]{2}{*}{ Indistance $x y$} & (omitted) & $-1.141^{* * * *}$ & $-1.143^{* * *}$ & (omitted) & $-0.863^{* * *}$ & $-0.888^{* * * *}$ \\
\hline & & $(0.163)$ & $(0.125)$ & & $(0.132)$ & $(0.167)$ \\
\hline \multirow[t]{2}{*}{ CLB $_{x y}$} & (omitted) & 0.062 & 0.063 & (omitted) & 0.319 & 0.296 \\
\hline & & (0.494) & $(0.358)$ & & (0.394) & $(0.415)$ \\
\hline \multirow[t]{2}{*}{ Crisist } & $-0.169^{* *}$ & $-0.179^{* *}$ & $-0.179^{* * *}$ & $-0.142^{*}$ & -0.047 & $-0.142^{*}$ \\
\hline & $(0.080)$ & $(0.076)$ & $(0.044)$ & (0.079) & $(0.075)$ & $(0.079)$ \\
\hline \multirow[t]{2}{*}{ Post-crisist } & $-0.216^{* *}$ & $-0.244^{* *}$ & $-0.243^{* * *}$ & $-0.231^{* *}$ & -0.08 & $-0.231^{* *}$ \\
\hline & $(0.102)$ & $(0.095)$ & $(0.080)$ & $(0.102)$ & $(0.092)$ & $(0.102)$ \\
\hline \multirow[t]{2}{*}{$\alpha_{0}$} & $-14.789^{* * *}$ & -4.158 & -4.151 & $-17.259^{* * * *}$ & $-4.567^{*}$ & $-9.429^{* * * *}$ \\
\hline & $(3.044)$ & (2.903) & (3.849) & $(3.035)$ & (2.704) & (3.034) \\
\hline $\begin{array}{l}\text { Hausman test } \\
\text { preference }\end{array}$ & RE (Prob & $=0.573)$ & & \multicolumn{2}{|c|}{$\mathrm{FE}($ Prob $>$ ChiSq $=0.0077)$} & \\
\hline R-sq & 0.093 & 0.4139 & & 0.1085 & 0.4678 & \\
\hline No. of observation & \multicolumn{3}{|c|}{1155} & \multicolumn{3}{|c|}{1155} \\
\hline $\begin{array}{c}\text { F (all coefficient)/ } \\
\text { Wald } \chi^{2}\end{array}$ & $81.51^{* * *}$ & $412.19^{* * *}$ & $51.30^{* * *}$ & $100.78^{* * * *}$ & $525.64^{* * *}$ & $436.19^{* * * *}$ \\
\hline
\end{tabular}


Appendix Table 7: Industry-specific results - Agriculture industry

\begin{tabular}{|c|c|c|c|c|c|c|}
\hline & \multicolumn{3}{|c|}{ Export } & \multicolumn{3}{|c|}{ Imports } \\
\hline & $\begin{array}{l}\mathrm{FE} \\
(1)\end{array}$ & $\begin{array}{l}\text { RE } \\
\text { (2) }\end{array}$ & $\begin{array}{c}\mathrm{AR} \text { (1) HT } \\
\text { (3) }\end{array}$ & $\begin{array}{l}\text { FE } \\
(4)\end{array}$ & $\begin{array}{l}\mathrm{RE} \\
(5)\end{array}$ & $\begin{array}{l}\text { HT } \\
(6) \\
\end{array}$ \\
\hline $\operatorname{lngdp_{x}}$ & $\begin{array}{c}0.969^{* * * *} \\
(0.275)\end{array}$ & $\begin{array}{c}0.793^{* * *} \\
(0.099)\end{array}$ & $\begin{array}{c}0.758^{* * *} \\
(0.092)\end{array}$ & $\begin{array}{c}-0.159^{* * *} \\
(0.301)\end{array}$ & $\begin{array}{c}0.349^{* * *} \\
(0.123)\end{array}$ & $\begin{array}{l}0.301^{* *} \\
(0.123)\end{array}$ \\
\hline $\operatorname{lngdp} y$ & $\begin{array}{c}0.097 \\
(0.299)\end{array}$ & $\begin{array}{c}0.552^{* * * *} \\
(0.076)\end{array}$ & $\begin{array}{c}0.507^{* * * *} \\
(0.088)\end{array}$ & $\begin{array}{c}0.894 \\
(0.249)\end{array}$ & $\begin{array}{c}0.475^{* * * *} \\
(0.130)\end{array}$ & $\begin{array}{c}0.511^{* * * *} \\
(0.185)\end{array}$ \\
\hline lndistance ${ }_{x y}$ & (omitted) & $\begin{array}{c}-0.669^{* * * *} \\
(0.134)\end{array}$ & $\begin{array}{c}-0.627^{* * * *} \\
(0.147)\end{array}$ & (omitted) & $\begin{array}{l}-0.390 \\
(0.285)\end{array}$ & $\begin{array}{c}-0.348 \\
(0.284)\end{array}$ \\
\hline $\mathrm{CLB}_{\mathrm{xy}}$ & (omitted) & $\begin{array}{c}0.833^{* * * *} \\
(0.232)\end{array}$ & $\begin{array}{c}0.832^{\text {**** }} \\
(0.215)\end{array}$ & (omitted) & $\begin{array}{l}1.496^{* * * *} \\
(0.399)\end{array}$ & $\begin{array}{l}1.484^{*} \\
(0.859)\end{array}$ \\
\hline Crisist & $\begin{array}{c}-0.014 \\
(0.033)\end{array}$ & $\begin{array}{l}-0.088^{*} \\
(0.046)\end{array}$ & $\begin{array}{l}-0.052 \\
(0.035)\end{array}$ & $\begin{array}{c}0.054 \\
(0.056)\end{array}$ & $\begin{array}{c}0.049 \\
(0.061)\end{array}$ & $\begin{array}{c}0.053 \\
(0.118)\end{array}$ \\
\hline Post-crisis $\mathrm{t}_{\mathrm{t}}$ & $\begin{array}{l}-0.158 \\
(0.114)\end{array}$ & $\begin{array}{c}-0.321^{* * * *} \\
(0.116)\end{array}$ & $\begin{array}{c}-0.264^{* * *} \\
(0.117)\end{array}$ & $\begin{array}{l}-0.009 \\
(0.099)\end{array}$ & $\begin{array}{l}-0.016 \\
(0.103)\end{array}$ & $\begin{array}{c}-0.011 \\
(0.149)\end{array}$ \\
\hline$\alpha_{0}$ & $\begin{array}{c}-8.448^{* * *} \\
(2.725)\end{array}$ & $\begin{array}{c}-10.608^{* * * *} \\
(2.466)\end{array}$ & $\begin{array}{c}-8.859^{* * * *} \\
(2.302)\end{array}$ & $\begin{array}{l}-0.197 \\
(2.862)\end{array}$ & $\begin{array}{c}0.102 \\
(3.043)\end{array}$ & $\begin{array}{l}-0.144 \\
(4.673)\end{array}$ \\
\hline Hausman test preference & \multicolumn{2}{|c|}{ FE $($ Prob $>$ ChiSq $=0.0064)$} & & \multicolumn{2}{|c|}{ RE $($ Prob $>$ ChiSq $=0.0514)$} & \\
\hline R-sq & 0.212 & 0.440 & & 0.007 & 0.202 & \\
\hline No. of observation & & 825 & & & 825 & \\
\hline $\mathrm{F}$ (all coefficient)/ Wald $\chi^{2}$ & $58.89^{* * *}$ & $363.65^{* * *}$ & $303.40^{* * *}$ & $36.93^{* * * *}$ & $149.86^{* * *}$ & $101.07^{* * * *}$ \\
\hline
\end{tabular}

Appendix Table 8: Industry-specific results - Machinery industry

\begin{tabular}{|c|c|c|c|c|c|c|}
\hline & \multicolumn{3}{|c|}{ Export } & \multicolumn{3}{|c|}{ Imports } \\
\hline & $\begin{array}{l}\mathrm{FE} \\
(1)\end{array}$ & $\begin{array}{l}\mathrm{RE} \\
(2)\end{array}$ & $\begin{array}{c}\mathrm{AR}(1) \mathrm{HT} \\
\text { (3) }\end{array}$ & $\begin{array}{l}\mathrm{FE} \\
(4)\end{array}$ & $\begin{array}{l}\mathrm{RE} \\
(5)\end{array}$ & $\begin{array}{l}\text { HT } \\
(6)\end{array}$ \\
\hline $\operatorname{lngdp_{x}}$ & $\begin{array}{l}0.802^{* * *} \\
(0.274)\end{array}$ & $\begin{array}{c}0.299^{* * * *} \\
(0.092)\end{array}$ & $\begin{array}{c}0.356^{* * *} \\
(0.133)\end{array}$ & $\begin{array}{c}0.196 \\
(0.399)\end{array}$ & $\begin{array}{l}1.174^{* * *} \\
(0.142)\end{array}$ & $\begin{array}{c}0.989^{* * * *} \\
(0.159)\end{array}$ \\
\hline $\operatorname{lngdp} p_{y}$ & $\begin{array}{c}0.378 \\
(0.309)\end{array}$ & $\begin{array}{c}0.767^{* * *} \\
(0.111)\end{array}$ & $\begin{array}{c}0.741^{* * *} \\
(0.113)\end{array}$ & $\begin{array}{l}1.187^{* * *} \\
(0.354)\end{array}$ & $\begin{array}{c}0.272 \\
(0.168)\end{array}$ & $\begin{array}{c}0.457^{*} \\
(0.238)\end{array}$ \\
\hline lndistance $_{\mathrm{xy}}$ & (omitted) & $\begin{array}{c}-1.311^{* * *} \\
(0.214)\end{array}$ & $\begin{array}{c}-1.290^{* * *} \\
(0.215)\end{array}$ & (omitted) & $\begin{array}{c}-2.026^{* * * *} \\
(0.268)\end{array}$ & $\begin{array}{c}-1.867^{* * * *} \\
(0.369)\end{array}$ \\
\hline $\mathrm{CLB}_{\mathrm{xy}}$ & (omitted) & $\begin{array}{l}-0.380 \\
(0.383)\end{array}$ & $\begin{array}{l}-0.392 \\
(0.489)\end{array}$ & (omitted) & $\begin{array}{l}-0.096 \\
(0.429)\end{array}$ & $\begin{array}{c}-0.147 \\
(1.118)\end{array}$ \\
\hline Crisist & $\begin{array}{c}-0.185^{* * *} \\
(0.039)\end{array}$ & $\begin{array}{c}-0.097^{* *} \\
(0.051)\end{array}$ & $\begin{array}{c}-0.115^{* *} \\
(0.049)\end{array}$ & $\begin{array}{c}-0.137^{* *} \\
(0.057)\end{array}$ & $\begin{array}{c}-0.091 \\
(0.072)\end{array}$ & $\begin{array}{l}-0.105 \\
(0.152)\end{array}$ \\
\hline Post-crisis ${ }_{\mathrm{t}}$ & $\begin{array}{c}-0.535^{* * *} \\
(0.112)\end{array}$ & $\begin{array}{c}-0.395^{* * *} \\
(0.114)\end{array}$ & $\begin{array}{c}-0.423^{* * *} \\
(0.090)\end{array}$ & $\begin{array}{c}-0.444^{* * * *} \\
(0.101)\end{array}$ & $\begin{array}{c}-0.369^{* * * *} \\
(0.143)\end{array}$ & $\begin{array}{c}-0.393^{* *} \\
(0.192)\end{array}$ \\
\hline$\alpha_{0}$ & $\begin{array}{c}-10.147^{\text {**** }} \\
(2.898)\end{array}$ & $\begin{array}{c}3.170 \\
(2.257)\end{array}$ & $\begin{array}{c}2.221 \\
(2.626)\end{array}$ & $\begin{array}{c}-16.123^{* * * *} \\
(4.280)\end{array}$ & $\begin{array}{l}-2.075 \\
(3.655)\end{array}$ & $\begin{array}{l}-3.199 \\
(6.014)\end{array}$ \\
\hline Hausman test preference & \multicolumn{2}{|c|}{$\mathrm{FE}($ Prob $>\mathrm{ChiSq}=0.0245)$} & & \multicolumn{2}{|c|}{ FE $($ Prob $>$ ChiSq $=0.0008)$} & \\
\hline R-sq & 0.065 & 0.351 & & 0.040 & 0.505 & \\
\hline No. of observation & & 825 & & & 825 & \\
\hline $\mathrm{F}$ (all coefficient)/ Wald $\chi^{2}$ & $40.02^{* * *}$ & $206.6^{* * *}$ & 214.53 & $25.61^{* * *}$ & $214.86^{* * * *}$ & $180.00^{* * * *}$ \\
\hline
\end{tabular}

